\title{
Szymon Askenazy as a diplomat of the Reborn Poland (1920-1923)
}

Zarys treści: Studium jest próbą opracowania działalności dyplomatycznej Szymona Askenazego po odrodzeniu państwa polskiego, a zwłaszcza najmniej znanej karty, jaką była jego walka o kształt granic odrodzonej Rzeczypospolitej w Genewie 1921-1923. Był to jeden z najgorętszych okresów w historii dyplomacji polskiej. Askenazy reprezentował interesy odrodzonej Polski, będącej jego ojczyzną z wyboru. Jego działania nie spotkały się jednak z powszechną aprobatą głównych obozów polityki polskiej. Był też rzecznikiem koncepcji podwójnej świadomości Żydów: żydowskiej i polskiej. Jego zdaniem Żydzi zachować winni swoją religię i kulturę, ale zarazem "niechaj połączą to z poczuciem polskości i patriotyzmu polskiego".

Outline of content: The study is an attempt to describe the diplomatic activities of Szymon Askenazy after the revival of the Polish state, and especially their least known chapter, which was his struggle for the shape of the borders of the reborn Republic of Poland in Geneva, 1921-1923. It was one of the hottest periods in the history of Polish diplomacy. Askenazy represented the interests of the reborn Poland, his chosen homeland. However, his actions did not always receive general approval of the main camps of Polish politics. He was also a spokesperson for the concept of Jews' double consciousness: Jewish and Polish. In his opinion, Jews should maintain their religion and culture, but at the same time "let them combine it with a sense of Polishness and Polish patriotism".

Słowa kluczowe: Szymon Aszkenazy, dyplomacja polska 1921-1923, historia Polski 1918-1939, polska polityka zagraniczna w okresie międzywojennym, Żydzi w Polsce, podwójna świadomość Żydów

Keywords: Szymon Askenazy, Polish diplomacy 1921-1923, Polish history 1918-1939, Polish foreign politics in the interwar period, Jews in Poland, double consciousness of Jews

The restoration of Poland opened the field of public service to Szymon Askenazy. He was ready for it - he put a lot of energy and dedication into it, witnesses of the events agree. "To the service of the reborn Republic of Poland he gave his vast 
knowledge, incredible awareness of political issues, times and people, exceptional understanding of many foreign circles and his fierce, stubborn will to fight for the Polish national interest to the very end" - Marian Kukiel will write after the death of his Master. ${ }^{1}$

This study is an attempt to examine the diplomatic activities of Szymon Askenazy after the rebirth of the Polish state. Due to the significant size of this article, we have omitted the period of World War I, already well explored. Askenazy's activities at the time were a kind of a diplomatic service to a non-existent state. His work was "diplomacy without letters of credence", if we were to refer to the titular phrase by Hans-Henning Hahn from his book about Adam Jerzy Czartoryski. ${ }^{2}$ Another experience - fully official - was Askenazy's role in the work of the Bureau of Foreign Propaganda by the Council of Ministers, which due to the significant size of this text we had to omit.

By taking on the first source study of an unexplored chapter in the life of this eminent historian, we want to make a new contribution to the history of diplomacy of the second Republic of Poland at the beginning of its existence - in the struggle for the state borders. We may plan to discuss Askenazy's public service more fully in the future.

\section{I}

\section{Against George Barnes' resolution and for the rights of Poland in the Free City of Danzig}

At the headquarters of the League of Nations in Geneva, member states accredited delegates in the rank of envoys (ministers plenipotentiary). The Polish government passed a resolution on this matter in August 1920. The obligations of a delegate were entrusted to the former Prime Minister Ignacy Paderewski. Szymon Askenazy was appointed his deputy.

In the atmosphere of victory in Poland, "a very favourable climate towards Poland quickly formed within the League of Nations", reported Paderewski to Sapieha on 22 September $1920 .{ }^{3}$ However, this soon changed when the Polish Army - in pursuit of the enemy - began to occupy territories to the East of the line marked out by the Supreme Council of the Principal Allied and Associated Powers on 8 December 1919, the Curzon Line. Concerns appeared in Paris and London that, as Lord Curzon wrote to the British Ambassador in Paris, Lord Derby, on 7 October 1920 - the Polish attempts to impose peace on Bolsheviks

\footnotetext{
M. Kukiel, “Szymon Askenazy”, Przegląd Współczesny, vol. 54, 1935, p. 332.

${ }^{2}$ Dyplomacja bez listów uwierzytelniających. Polityka zagraniczna Adama Jerzego Czartoryskiego 1830-1840, transl. M. Borkowicz, Warszawa, 1987.

3 Archiwum Polityczne Ignacego Paderewskiego (hereinafter: APP), vol. 2, Warszawa, 1974, p. 498.
} 
may bring "future unrest in Eastern Europe, which eventually would make it impossible to establish peace". ${ }^{4}$

The Polish victory on the banks of Vistula was hardly the end of the British vision of "ethnographic Poland". ${ }^{5}$ French expectations of a reborn national Russia, free from Bolshevism, were also making their mark. On 1 October 1920, the Prime Minister and Minister of Foreign Affairs of the French Republic sent an instruction to the envoy in Warsaw, de Panafieu, which included words of appeal to Poles that they remained "justes et modérés dans sa victoire". 6 This meant a refusal to grant Poland rights to the territories east of the Curzon Line.

It is very interesting to us how Askenazy looked at the state of Polish affairs in the international power system. First of all, preserved documents allow us to believe that he supported a correction of the Polish policy in favour of seeking a dialogue with the United Kingdom, and against total identification with France. Writing on 2 September 1920 to the Head of State and referring to the issue of Eastern borders, he noted: "In these things France will never go with us against Russians and England. Without England we will not manage. England harmed us shamefully in five major cases (Danzig, Silesia, Eastern Galicia, Jews, Bolshevism). But it is impossible to take offence at the world's largest country, with a population of 450 million. We need to talk with them. We have economic data for it and, what is most important, political". ${ }^{8}$ We are not able to make an unequivocal comment about these words. In substance, Askenazy was quite right, however we must remember that at the time Poles had very little to offer to England in order to win it over.

On 19 November 1920, the third British delegate, George Barnes, put forward a proposal on the forum of the General Assembly of the League which contained the demand "that the League intervenes in the Soviet-Polish peace negotiations" launched after signing the ceasefire on 12 October of that year, arguing this need with "a threat of resuming the war". Paderewski deemed the mood of the Assembly towards Poland as "rather unfavourable". "Holding on closely to France", he wrote, "I am trying to remove England's prejudices and I ask for vigorous support in this direction in Warsaw as well".

Barnes' proposal should be linked with the attempts of the British Labour Party to make the League of Nations deal with the issue of the Soviet-Polish conflict

${ }^{4}$ Documents on British Foreign Policy 1919-1939 (hereinafter: DBFP), First Series, vol. XI, London, 1961, p. 587.

5 Andrzej Nowak analyses the British ideas regarding the Polish issue anew, based on valuable material, in his most recent book: Pierwsza zdrada Zachodu. 1920 - zapomniany appeasement, Kraków, 2015.

${ }^{6}$ Archives du Ministère des Affaires Étrangères (Paryż), Europe 1918-1940, Pologne, vol. 130.

7 Ibid. The French even wanted Poland to take a decision to respect the "border" with Lithuania and its "capital" in Wilno (sic!).

8 Józef Pilsudski Institute of America (New York), archival collection "General Adjutancy of the Commander-in-Chief" (hereinafter: JPIA, GACC), box 32.

9 APP, vol. 2, p. 571. 
and not allow the victory of Poland to be exploited in the form of territorial acquisitions in the east which would not correspond to the ethnographic reality. In a conversation with Askenazy, Barnes directly asked "why would Poland not move back to the Curzon Line". ${ }^{10}$ In this situation, the task of the Polish delegation in Geneva was the fight to remove this matter from the agenda. ${ }^{11}$

The case seemed difficult, as France, which until then generally supported Poland in its territorial conflicts (with the exception of the conflict with Czechoslovakia about Cieszyn Silesia), also did not want Polish borders in the east to be pushed too far, what - in their view - would hinder a future Polish-Russian reconciliation. Hopes of restoring a "national Russia", rather than a Bolshevik one, which could become France's first ally in the east, persisted in Paris. ${ }^{12}$ Poland became an ally of the victorious France, but only as an une alliée de remplacement - instead of Russia. ${ }^{13}$ If the matter of the Soviet-Polish border was brought to the forum of the League, the Polish government could not count on Italy either, as the creators of this country's foreign policy repeatedly expressed their view that annexation of substantial territories in the east would be beneficial neither for Poland nor for European peace. The Foreign Minister Carlo Sforza, open to understanding Polish interests, advised Poland to start immediate peace negotiations with the Soviets, and deemed the Kiev Offensive in May 1920 an undisputed error. ${ }^{14}$

Fortunately for the Polish side, the League of Nations failed to show interest in its interference in the Polish-Soviet conflict, apparently considering it a source of new, unnecessary difficulties for itself - in addition to many other. What is more, it was not without importance that the Soviet government would rather not have "capitalist powers" interfere in its negotiations with Poland. After talks with Barnes, Lord Balfour, the Belgian Foreign Minister Paul Hymans and the Swiss Foreign Minister Giuseppe Motta, Paderewski decided the "fear of the League's intervention [in] Riga negotiations was unfounded", and that is how he put it to Sapieha in a telegram on 29 November $1920 .{ }^{15}$

On 1 December, Paderewski decided that Barnes' proposal, "although conceived against us", could yet "give us a chance not only to counter the blow, but even to achieve a moral success. This case from the Polish point of view is completely clean. We can be proud of it. We have nothing to hide there, we just need to immediately

${ }_{10}$ Republic of Poland Delegation protocol of 1 December 1920, APP, vol. 2, p. 587.

11 M. Nowak-Kiełbikowa, Polska - Wielka Brytania w latach 1918-1923, Warszawa, 1975, p. 264.

12 There were even some unusual ideas, e.g. to include Wrangel in the Riga talks (as reported by Askenazy to the Foreign Ministry on 10 October 1920); see J. Kukułka, Francja a Polska po traktacie wersalskim 1919-1922, Warszawa, 1970, p. 414.

13 It was broadly presented by P.S. Wandycz, France and her Eastern Allies 1918-1925. French-Czechoslovak-Polish Relations from Paris Peace Conference to Locarno, Minneapolis, 1962.

${ }^{14}$ Une déclaration de M. Sforza sur la question Russo-polonaise, 6 August 1920, Archives of Modern Records in Warsaw (hereinafter: AAN), Akta Erazma Piltza, cat. no. 32.

15 APP, vol. 2, p. 582. 
define the limits of the discussion, we positively cannot agree to a public debate of matters involved in our negotiations in Riga, which, according to the telegram from the Minister of Foreign Affairs, are developing rather successfully". ${ }^{16}$

The forum of the General Assembly began to put pressure on Barnes to withdraw his proposal. However, Askenazy doubted that it would be possible to make "the proposal withdrawn at all" and considered it advisable in such a situation to "limit the discussion, so as not to hinder our negotiations in Riga". Paderewski believed that it should be done openly, not by fighting for taking the proposal off the agenda, but by clearly presenting Poland's stance during the Assembly debate. Importantly, in an interview with Askenazy, lord Balfour distanced himself from Barnes' actions, who, according to the Polish envoy, "in his speeches is led by the class policy of the English proletariat, which favours the Bolsheviks". ${ }^{17}$

On 4 December 1920, the fate of Barnes' proposal was decided in favour of Poland. The last attempt to internationalise the Polish-Soviet conflict did not yield any results. Two days later, Paderewski reported to Sapieha that the matter was "a complete success for us". "Our position", wrote the First Delegate of the Republic of Poland, "was very strong, the issue was clear, with nothing to hide. I have been opposed here to the great manoeuvres unworthy of our national position, aimed at preventing the proposal from being put forward at all costs. The debate over Barnes' proposal has been widely regarded here as 'the Polish day". In Paderewski's opinion, "Bourgeois' response was excellent" - he defended the current position of the Council of the League in the Polish-Soviet conflict, i.e. that of non-interference. Poland received support also from the Norwegian foreign minister, Fridtjof Nansen, "perhaps not very close to us in his heart, he saw fit to start his speech from assertions of admiration and sympathy for Poland". The debate was chaired by Hymans. He did not allow a ballot over Barnes' proposal, stating "very tactfully", that the proposer "deemed sufficient the explanation he received". ${ }^{18}$ The campaign of the British delegate ended in a failure.

The proceedings of the 4 December 1920 were a success of the Polish diplomacy within the League of Nations. The Polish-Soviet border was drawn up without the interference of a third party, by agreement between the two sides, until then involved in a conflict. In its resolution of 18 December, the Council of the League stated that "it has not and would not get involved in the dispute between Poland and the Soviet Union, nor in the negotiations in Riga, and cannot be held responsible for hindering these negotiations". ${ }^{19}$ Paderewski wrote to Sapieha on 31 December 1920: "The First Assembly of the League of Nations was unexpectedly successful for us. The crafty plan to bring Poland to the tribunal of nations in the role of the

\footnotetext{
${ }^{16}$ Republic of Poland Delegation protocol of 1 December 1920, APP, vol. 2, p. 587.

17 Ibid.

18 Paderewski to Ministry of Foreign Affairs, 6 December 1920, APP, vol. 2, p. 597.

19 APP, vol. 2, pp. 614-615 (Askenazy's report of 27 December 1920).
} 
accused came to nothing. The Bolshevik affair, which we had been threatened with from the very first moment, and in which they messed a great deal, was settled without great difficulty. Owing to the exceptionally good relations with the main delegates, neither Żeligowski nor the Galician case were dragged into the plenary". ${ }^{20}$

The Polish-Soviet peace treaty in Riga, signed without the help or participation of the major powers on 18 March 1921, was a compromise which would last twenty years. Its importance to the interwar Central and Eastern Europe was significant, although still tends to be underestimated. ${ }^{21}$ On 15 March 1923, this border would be approved by the Conference of Ambassadors.

In the autumn of 1920, another crucial matter held the attention of the Polish delegation at the League of Nations. It was the agreement with the Free City of Danzig, which was to define the rights of Poland and normalise the relations between this entity and the Polish state in the understanding of international law.

As we know, at the Paris Peace Conference the Allied powers decided to establish the Free City of Danzig in order to reconcile two types of arguments: protecting the Polish right of access to the sea, and maintaining the German character of the city. ${ }^{22}$ After the Great War, four such special territories were established. Aside from the Free City of Danzig, these were Klaipeda and Fiume (Rijeka), as well as the Saar Basin. ${ }^{23}$ All these territories were under the control of the League of Nations. The Saar Basin and Danzig became the most important among them, being the real "barometers of European tension", as a Polish historian put it. ${ }^{24}$

10 January 1920 saw the introduction of the Treaty of Versailles, which created the Free City of Danzig. Four days earlier, on 6 January of that year, Germany relinquished Danzig to the Principal Allied and Associated Powers. On 15 November 1920, the authorities of the Free City of Danzig were formally appointed as a territorial formation of a "semi-public" character, with its own constitution, guaranteed by the League of Nations. ${ }^{25}$ The Free City was incorporated into the Polish customs area. Its foreign policy was to be led by Poland. Poland was also granted the Port of Danzig. This was all the Treaty of Versailles said. A detailed normalisation of cases not included in the form of Treaty provisions was to take

20 APP, vol. 2, p. 618.

${ }^{21}$ Cf. J. Borzęcki, The Soviet-Polish Peace of 1921 and the Creation of Interwar Europe, New Haven, 2008.

${ }^{22}$ The original proposal of Cambon's Commission (for Polish Affairs) to annex Danzig into Poland, collapsed after opposition from the British delegation. In detail about these matters, M.H. Serejski, "Jak ważyły się losy Gdańska przed ostatnią decyzją zwycięskich mocarstw", Dzieje Najnowsze 2 (1970), no. 1, pp. 73-95.

23 Cf. H. Batowski, Między dwiema wojnami 1919-1939. Zarys historii dyplomatycznej, Kraków, 1988, pp. 55-57 and 64-65.

24 S. Sierpowski, Liga Narodów w latach 1919-1926, Wrocław and Warszawa, 2005, pp. 143-179.

25 Polish instruction of international law consistently supported the thesis that the Free City of Danzig is not a state, but has a "semi-state" character; see J. Makowski, Zagadnienie państwowości W.M. Gdańska, Warszawa, 1934. 
place by way of a special convention between the government of Poland and the Free City, negotiated under the auspices of the League. ${ }^{26}$

The convention was to become an instrument for implementing the provisions of article 104 of the Treaty of Versailles. The talks on the matter were led by the delegations of the Polish government and representatives of the Free City of Danzig. They lasted several months and took place with the interference of the Council of Ambassadors, which dealt with cases that had not been settled after the Peace Conference, after its close in August 1919. Poland was represented by Paderewski and Askenazy, while Danzig - the President of the Senate Heinrich Sahm.

Szymon Askenazy seemed particularly predestined to take a place among the Polish negotiators of the Poland-Danzig convention. He gained renown as an expert in the matters of Danzig thanks to his book Dantzig \& Poland, which attempts to summarise the history of Danzig and its role in relation to the Republic, published in 1919 in Polish and later also in other languages. It was an elaboration of a 1904 essay about Danzig. "On my advice”, wrote Askenazy's student Janusz Iwaszkiewicz, "he has expanded and added depth to his old sketch on Danzig matters, and offered it to our delegation for the conference". ${ }^{27}$ In this way he wished to bring back history, preserve among Poles "the awareness of physical and historical rights of Poland" to Danzig, and to give "their clear and convincing demonstration to the world" ${ }^{28}$ Tadeusz Gustaw Jackowski recalled that for the newly organised unit at the Ministry of Foreign Affairs called "Danzig Bureau", where he began his work in the foreign service, Askenazy's book was truly "valuable help". ${ }^{29}$

"There is only one healthy and fair solution of the Danzig case as an integral part of the Polish cause. It is the simplest solution, in the interests of the city as well as Poland and Europe, prescribed once and for all by the unerring law of nature and history. Danzig should be simply and fully returned to Poland, and Poland to Danzig. Then, with no detriment to its current German population, with no pressure on it, and indeed for its greatest good, by voluntary, natural selection, under the influence of factors even more favourable than before the partitions, factors of modern, more intensive economic exchange with Poland, closer communication with the Polish environment, with Poznań, Warsaw, Kraków, and a quicker pulse of national culture, the old, reborn Danzig, in the reborn Poland, will be a great, powerful and happy Polish city", wrote Askenazy in the conclusion to his book Dantzig of Poland. ${ }^{30}$ In the diplomatic world it was therefore obvious that Askenazy had been particularly interested in matters of Danzig for quite some time.

${ }^{26}$ For the time being, to avoid chaos, a temporary agreement was in operation, signed on 22 April 1920.

27 J. Iwaszkiewicz, “Szymon Askenazy 1867-1935”, Ateneum Wileńskie 11 (1936), p. 7.

28 S. Askenazy, Przedmowa in the first edition, Gdańsk a Polska, Poznań, Wilno and Zakopane, 1919, 2nd ed., p. V. Written in December 1918.

29 T.G. Jackowski, W walce o polskość, Kraków, 1972, p. 247.

30 Askenazy, Gdańsk a Polska, p. 166. 
"The Danzig question" was for him "an integral part of the Polish question". ${ }^{31}$ Also the French historian Abel Mansuy gave Askenazy high marks for the book, published in French and German in 1919, and two years later in English.

However, Danzig was not restored to Poland, as Askenazy had wished. Under the influence of the British delegation and as a result of the involvement of Lloyd George, the Free City was established. The Poland-Danzig convention talks were complicated. The Danzig side wanted to erode Poland's rights in Danzig, following from the article 104 of the peace treaty, as much as possible.

After the negotiations ended, the signing of the convention was planned for 23 October 1920, but in the face of objections from both parties, it was moved to 9 November 1920. "The Conference of Ambassadors rejected a number of Polish demands and the final outcome of the negotiations was not too favourable for Poland" - judged the historian Henryk Batowski. ${ }^{32}$

On 9 November 1920, Paderewski wrote to Sapieha: "Everything the zealous labour of the delegation could achieve, was achieved. Whatever their personal efforts and relations were able to obtain, was obtained. Nothing more, except for some concessions in the distribution of goods, can be counted on. Article one hundred and seven does not enter the convention and will not be considered later on. Due to the fact that the protection of the Free City was entrusted to the $\mathrm{L}$ [eague of] $\mathrm{N}$ [ations], the Conference of Ambassadors concluded that granting us a mandate to defend Danzig is a decision for the League of Nations, and have recommended this matter to the League in kindly spirit. The case will be decided in Geneva no later than on the fourteenth. On the fifteenth, The Free City will be recognised. In the event of our refusal to sign, the Conference will keep its original draft of the convention without any amendments in our favour. The deadline for signing is 15 November. They are requesting a reply. The government must provide it. I could not give it". ${ }^{33}$ The contents of the convention diminished Poland's rights. The right to defend the Free City was not entrusted to the Polish state.

A delay on the Polish side and postponing the date of signing the convention was not possible, as René Massigli, the representative of France, threatened that if Paderewski did not sign the convention, the British government would "consider the whole issue to be newly opened" ${ }^{34}$ The former Prime Minister accepted this warning.

As to Polish rights in Danzig, Askenazy did not agree with Paderewski's view and believed that its unfavourable content should lead to a refusal to sign. On 12 December 1920, he wrote to Sapieha: "The military mandate challenged. England declared itself against the fortifications, France did not support us. These are the

${ }^{31}$ Cf. S. Askenazy, Wczasy historyczne, II, Warszawa and Kraków, 1904, p. 166.

32 Batowski, Między dwiema wojnami, p. 55.

33 APP, vol. 2, pp. 556-557.

34 Telegram from M. Zamoyski to I. Paderewski, 17 November 1920, APP, vol. 2, p. 569. 
effects of the fateful error that the case was led by Mr. Paderewski (as well as Mr. Wielowiejski, who with his characteristic combination of utter ignorance and arrogance has brilliantly contributed to jeopardising the case and is severely liable for it), and in particular signing the convention of 9 November. Further effects of this case are simply incalculable in every respect. I believe that we will have to try and influence England through American mediation. Not having anything to do with this matter, I am only mentioning it under the fresh, heavy impression of today's decision, which, being only the start of further trouble, Your Highness the Minister and the Government will hopefully be able to successfully repeal" ${ }^{35}$ He therefore considered it a mistake to sign the convention. Was he right? It is difficult to be sure. British politics could cause new problems.

The agreement between the Republic of Poland and the Free City of Danzig from 9 November 1920, signed in Paris in order to implement the provisions of article 104 of the peace treaty with Germany comprised five chapters and 40 articles. The act far from fulfilled the basic demands of Poland. ${ }^{36}$ It was undoubtedly a compromise between the Polish interests and Danzig's emancipatory attempts. The Paris Convention established the Port and Waterways Council, on the principle of parity, which stripped Poland of many important privileges. The Port Council was to consist of no more than five representatives of each of the two sides (Poland and Danzig). It stipulated the election of a president, or entrusting this function to a citizen of the Swiss Confederation by the League of Nations. It gave Poland the right to import through the Port of Danzig any goods not prohibited by the Polish law. ${ }^{37}$

Danzig was included in the Polish customs area, but fees were to be taken not by Polish officers but by Danzig ones, under the supervision of inspectors. The Free City was to have a fleet under its own flag, and at the Port of Danzig Polish ships were to benefit from the same rights as the ships flying the Danzig flag. Poland received the use of railways within the territory of the Free City, as well as the right to create its own port, telephone and telegraph services. Danzig was covered by the provisions of the Treaty for the protection of national minorities of 28 June 1919, which meant granting the Polish population of Danzig a warranty of their rights. A representative of the Polish government, a Commissioner-General, was to reside in the Free City. ${ }^{38}$

35 Askenazy's letter to Sapieha, directed from Geneva, 12 December 1920, JPIA, GACC, box 32 .

36 F. Tommasini, Odrodzenie Polski, Warszawa, 1928, pp. 196-197. Key fragments of the contracted included in: Polska polityka zagraniczna w latach 1926-1932 [should be: 1926-1939]. Na podstawie szkiców min. Józefa Becka opracowała A.M. Cienciała, Paris, 1990, pp. 331-334.

37 A more detailed analysis in H. Stępniak, Polska i Wolne Miasto Gdańsk (1920-1939), Gdańsk, 2004, p. 75.

38 M.K. Kamiński, M.J. Zacharias, W cieniu zagrożenia. Polityka zagraniczna RP 1918-1939, 2nd ed., Warszawa, 1993, p. 50. 
Overall, Poland's rights resulting directly or seemingly from the provisions of article 104 of the Treaty of Versailles were restricted, as the Treaty was interpreted on the basis of appropriateness. At the same time, many new sources of dispute and tension were created, which would accompany the coexistence of Poland and the Free City until after 1 September 1939. A detailed executive layout of the Paris agreement was necessary, and was signed on 24 October 1921 in Warsaw. Negotiations were led by the Danzig senator Jewelowski and the Polish diplomat Pluciński. The Warsaw convention became an instrument to implement the Paris agreement.

From Poland's perspective, two issues seemed the most problematic and adversely resolved: (1) the Port of Danzig was not passed into the hands of the Polish administration; instead, the Port Council was created, constructed on the principle of parity. (2) The mandate of defence of the Free City was not granted to Poland.

A resolution granting Poland the Danzig defence mandate was submitted by the Japanese envoy to the League of Nations, Viscount Ishii (22 June 1921). ${ }^{39}$ However, it met with vigorous protest of the Danzig Senate. A representative of the Free City, Heinrich Sahm, spoke against granting the defence mandate to Poland "due to an alleged imperialism of Poland and its possessiveness towards Danzig". To support his arguments, he tendentiously quoted Askenazy's book, Dantzig \& Poland. He also proposed to give the mandate to any state which the High Commissioner of the League of Nations would come from. ${ }^{40}$ In December 1920, the Military Commission of the League of Nations stated the need to grant Poland the mandate of the defence of Danzig, but the matter was referred to the future Poland-Danzig special convention on the matter. ${ }^{41}$

The hopes to resume the case of the mandate appeared many times more. "Now there are talks of giving the mandate of land defence to Poland, and sea defence to England. Our military experts say that a war requires single command, which in this case may cause political conflicts; it is also very dangerous", wrote Sylwin Strakacz to Paderewski in May $1921 .^{42}$

In the end, it was only on 22 June 1921 that The Council of the League of Nations granted Poland the right to defend the Free City of Danzig, but it was on the condition that it must be at the request of the High Commissioner of the League. On 8 October that year, a temporary agreement was signed between Poland and Danzig about the right of warships to call to the Port of Danzig - the so-called port d'attache ${ }^{43}$ agreement. In 1924, already after Askenazy's departure from Geneva, Poland would be granted the right establish a transhipment weapon depot on the territory of the Free City - in Westerplatte.

39 Nowak-Kiełbikowa, Polska - Wielka Brytania, p. 334.

40 Report of the Republic of Poland Delegation for Minister Sapieha from 16 November 1920, APP, vol. 2, p. 567.

41 Paderewski's report from 2 December 1920, APP, vol. 2, p. 589.

42 Strakacz's report for Paderewski from 4-17 May 1921, APP, vol. 2, pp. 647-648.

43 Kamiński, Zacharias, W cieniu zagrożenia, p. 51. 
Askenazy would deal with Danzig matters many more times during his Geneva mission. And so, in September 1922, Danzig's financial position became very difficult. Negotiations were started to receive aid from the League of Nations. They were held by the High Commissioner of the League of Nations General Haking, Ernst Volkmann on behalf of the Senate of the Free City, and Askenazy as a representative of Poland. ${ }^{44}$

Askenazy was aware of the problematic legal and state regulations of the Danzig-Poland relations, but in the preface to the second edition of his book Dantzig \& Poland, written in March 1923, he expressed his faith that the relationship would become stronger in the future through peaceful regulations. "The legal state of affairs", he wrote, "should be accepted, but we can believe in its essential improvement. This improvement will sooner or later, peacefully, gradually but inevitably, be achieved by the inherent interest of Poland and Danzig, achieved by the mutual good will and common sense, achieved by life". ${ }^{45}$

Unfortunately, historical events did not fulfil this prophecy. In the era of the Weimar Republic, tensions between Poland and Danzig persisted. Poland's rights were systematically doubted and sabotaged. Strasburger's doctrine - the thesis claiming that normalisation of Poland-Danzig relations can be achieved through economic cooperation - also failed. Development of Hitlerism in Danzig brought the capture and domination of the Free City. Poland remained with Beck's concept, according to which it did not matter for the Polish government who held the power in the Free City and what its political system was, as long as Polish rights, guaranteed by the Peace Treaty and the Paris Convention, were not erased.

It is probably how it must be that no compromise will ever satisfy any of the parties involved. The Polish-Danzig convention was a half-measure. ${ }^{46}$ It was "only a framework of provisions concerning our relations with the Free City", according to Tadeusz Gustaw Jackowski. ${ }^{47}$ Assessing this situation, Beck will notice already during World War II, that "the statute of the Free City was probably the strangest and the most complex creation of the Treaty of Versailles. It seemed obvious that it was written this way in order to maintain an area of constant dispute between Poland and Germany, or at least material to trade Polish interests in favour of Germany". ${ }^{48}$ The League of Nations took on the responsibilities of the guarantor of the Free City, but had practically no executive instruments.

${ }^{44}$ Sierpowski, Liga Narodów, p. 352.

${ }_{45}$ Askenazy, Gdańsk a Polska, p. IX.

46 A detailed analysis of the rights of Poland in the Free City of Danzig is presented by Krzysztof Skubiszewski, "Kompetencje państwa polskiego w Wolnym Mieście Gdańsku”, Czasopismo Prawno-Historyczne 11 (1959), no. 2, pp. 145-184.

47 Jackowski, $W$ walce o polskość, p. 254.

48 Polska polityka zagraniczna w latach 1926-1939. Based on texts by Minister Józef Beck edited by A.M. Cienciała, Paris, 1990, p. 58. 
The vaguely regulated relations of Danzig to Poland will become a trigger for a future conflict. Of the three free cities in Europe, only Danzig survived until the outbreak of World War II. The other will be peacefully removed (Fiume - in 1924, the Saar Basin - in 1935, Klaipeda - in 1939). ${ }^{49}$ As we know, Hitler will demand that Poland cede the Free City. The Polish government will reject the demand. ${ }^{50}$ This will become a pretext to start the war.

The inefficiency of the League of Nations in Danzig proved to catalyse its discrediting in the eyes of Polish society. "In Poland, the twilight of the League of Nations' significance did not cause any deeper regrets, not just because in Geneva 'Poland's predilection to the role of a great power' was readily ridiculed, according to the diplomat Jan Meysztowicz. During the short period of its relative glory $[\ldots]$ the League did not protect Poland from German revisionism in relation to the 'corridor' and the Free City of Danzig, and even sometimes treated the complaints from the government of the Reich with understanding or as a means of pressure on the Polish government. It was, however, the source of humiliating and embarrassing interferences in Polish internal affairs [...] - based on the treaty for the protection of national minorities". ${ }^{51}$

\section{II}

\section{The Wilno dispute and the Polish-Lithuanian Confederation negotiations in Brussels}

The Polish-Lithuanian dispute over Wilno (Vilnius) consumed most of Askenazy's energy as the Polish envoy at the League of Nations. ${ }^{52}$

We should remember here that the Soviet counter-offensive in June 1920 resulted in the capture of Wilno and Wilno region by the Red Army. Under

49 The issue of Klaipeda in international politics is examined in detail by P. Łossowski, Kłajpeda kontra Memel. Problem Kłajpedy w latach 1918-1939-1945, Warszawa, 2007.

${ }^{50}$ M. Kornat, "W przededniu wojny. Żądania niemieckie wobec Polski 1938-1939”, Przegląd Polityczny 95 (2009), pp. 31-47.

51 J. Meysztowicz, Czas przeszły dokonany. Wspomnienia ze służby w Ministerstwie Spraw Zagranicznych latach 1932-1939, Kraków, 1984, pp. 115-116.

52 There are older expositions in historiography - see J. Ochota (real name Tadeusz Perkowski), Spór Litwy z Polska (Warszawa, 1935); W. Wielhorski, Polska a Litwa. Stosunki wzajemne w biegu dziejów (London, 1947); and the now classic works of Polish historians: H. Wisner, Wojna nie wojna. Szkice z przeszłości polsko-litewskiej (Warszawa, 1978), pp. 121-158; and mostly P. Łossowski, Konflikt polsko-litewski 1918-1920 (Warszawa, 1996). Special attention should be given to the study by J. Bardach, "Projekty organizacji kantonalnej Litwy oraz konfederacji polsko-litewskiej w 1921 roku”, in: id., O dawnej i niedawnej Litwie, Poznań, 1988, pp. 280-292. From the point of view of diplomatic history, Kukułka contributes a great deal, see Francja, pp. 423-439 (on the Lithuanian-Polish conflict and negotiations in Brussels). A noteworthy study in Lithuanian historiography: R. Žepkaité, Lietuviu tautos kova dèl Vilniaus 1919-1939 m. (Vilnius, 1964). 
the agreement of 10 July that year, Soviet Russia gave Wilno to the Republic of Lithuania. After the victory of Warsaw, and the resulting victorious operation at the Niemen River, Poland regained initiative in the conflict with Soviet Russia. The issue of Wilno and the Wilno region emerged. Poland had the choice of one of two options, debated at the session of the national Defence Council on 22 September 1920: relinquishing Wilno and the Wilno region, or "launching war activities against Lithuania", which would - it has to be taken into account - "cause an outcry in Europe, even though our situation justifies the proceedings". ${ }^{53}$

The Chief of General Staff, General Tadeusz Rozwadowski, believed that the Polish Army should occupy the whole territory of the Republic of Lithuania. This, however, would bring some severe consequences. The Chief of State, Józef Piłsudski, was of a different opinion - he believed that Polish-Lithuanian armed conflict should be avoided at all costs.

On 7 October 1920, a Polish-Lithuanian ceasefire was declared in Suwałki, signed on behalf of Poland by the representative of the Ministry of Foreign Affairs Juliusz Łukasiewicz. It established a demarcation line and ordered the cessation of military activities and exchange of prisoners of war between Poland and Lithuania. ${ }^{54}$ However, before this agreement came into force, on the orders of the Supreme Commander of the Polish Army, General Lucjan Żeligowski became the head of the improvised Lithuanian-Belarusian Division troops and, pretending to revolt against Poland, began his "March on Wilno" on 9 October 1920. The result of this operation was the proclamation of the so-called Central Lithuania.

There had already been a breach of the Lithuanian territory during the Polish offensive and the Battle of the Niemen River, which caused a corresponding resolution of the Council of the League of Nations. The French delegate, Leon Bourgeois, spoke in favour of the Lithuanian side. Askenazy made a statement that Żeligowski acted without the knowledge of the government, but of the volition of the Polish nation. ${ }^{55}$ Askenazy described the response of the international circles to the Polish action of 9 October 1920 as "an aggravation". ${ }^{56}$ The actions of General Żeligowski were generally described as a "Polish coup". The President of the Council of the League of Nations Leon Bourgeois spoke then about "the Polish occupation" of Wilno, giving it as an example of "breaking the commitments made by the Polish government to the League of Nations". ${ }^{57}$

53 Statement of Minister Sapieha - see A. Leinwand, J. Molenda (eds.), "Protokoły Rady Obrony Państwa”, Z Dziejów Stosunków Polsko-Radzieckich, vol. 1 (1965), p. 305.

${ }^{54}$ Cf. Wybór źródet do nauki prawa międzynarodowego, ed. B. Winiarski, Warszawa, 1938, pp. $248-$ 250 (the agreement was to enter into force at $12 \mathrm{pm}$ on 10 October, as an agreement with temporary modus vivendi).

55 Cf. Kukułka, Francja, p. 429, fn. 24.

56 Report for Minister Sapieha from 10 October 1920, CAW, cat. no. I. 440.12/6-7.

57 E. Milhaud, La France avait raison. Sécurité collective, Neuchâtel, 1945, p. 204. 
The Secretary General on the Quai d'Orsay Philippe Berthelot (who replaced Maurice Paléologue, former ambassador to Russia) also behaved in a hostile way. "Our former enemy and the creature of Izvolsky" - was Askenazy's judgement on Berthelot. He claimed, however, that the diplomat "doubted the quick revival of Russia and would be willing to adapt to us". ${ }^{58}$ In Europe, the rule of "a military party" in Poland was widely discussed. As we know, an idea appeared to force Marshal Piłsudski to resign from the office of the Head of State. Berthelot was to claim, however, that Piłsudski was "the only man today who can hold this position, and if he were actually to step down, he would return after a month". ${ }^{59}$

Poland failed to avoid an internationalisation of the Polish-Lithuanian dispute. On 29 October 1920, the Allied Supreme Council met in Brussels, mainly in order to establish the statute of the Permanent Court of International Justice in The Hague, and addressed also the issue of the Polish-Lithuanian conflict. "When leaving Paris", Askenazy wrote to the Ministry of Foreign Affairs in Warsaw, "I was under the impression that a strong aggravation against us, resulting from this matter, was still present in the League of Nations. Foregoing the unfortunate, neutralising decision of the League due to the sheer force of facts and necessity of our military action has not been forgiven by the Council of the League, and especially by the dominant English factors". ${ }^{60}$

The legal basis for the League's mediation in this conflict were twofold: (1) The de facto Prime Minister of the Polish government Władysław Grabski had agreed to surrender Wilno to Lithuania at the conference of the heads of governments of Allied powers in Spa (Belgium), held in July 1920. When asking for help for Poland, at war against Soviet Russia, Polish envoys were forced to accept all, very difficult demands of Allied powers, made under the pressure from the British Prime Minister Lloyd George. ${ }^{61}$ In the East, Polish troops were to withdraw to the line marked out on 8 December 1919 by the resolution of the Allied Supreme Council. The fate of the Cieszyn Silesia would be decided by the Council of Ambassadors, which happened indeed on 28 July 1920 - to the detriment of Poland. The Polish government was also forced to make concessions on a matter negotiated within the Poland-Danzig convention. ${ }^{62}$ Although Grabski refused Lloyd George's demand to return Wilno to Lithuanians, a "compromise" formula was negotiated, which

${ }^{58}$ Letter from Askenazy to Sapieha of 10 October 1920.

59 Tadeusz Romer (1st secretary of the delegation to Paris) to the chargé d'affaires in London Jan Ciechanowski, letter of 18 October 1920, The Polish Institute and Sikorski Museum in London (hereinafter: PISM), Embassy of the Republic of Poland in London, cat. no. A12.52/2.

${ }^{60}$ Cited from P. Łossowski, Po tej i tamtej stronie Niemna. Stosunki polsko-litewskie 1883-1939, Warszawa, 1985, p. 150.

61 The Polish delegation was composed of: chairman Patek, as well as Piltz, Kazimierz Olszowski and Kajetan Morawski, and experts Józef Wielowieyski, J. Mrozowski and General Tadeusz Rozwadowski (an expert on military affairs). Grabski arrived at the decisive moment and presided.

${ }^{62}$ Kamiński, Zacharias, W cieniu zagrożenia, pp. 42-43. Cf. also P. Wandycz, "Konferencja w Spa", Kultura 6 (1959), pp. 136-138. 
stated that Poland accepted that Wilno would remain temporarily in the hands of Lithuania, however, not definitively, as the matter would be settled by way of agreement at the peace conference. ${ }^{63}$ The Spa conference was the largest defeat of the Polish diplomacy, as Piotr Wandycz rightly described it. ${ }^{64}$ Incidentally, Polish concessions were unproductive from the very beginning, as Grabski's question - whether an invaded Poland could unreservedly count on the military help of the Allied powers - received an unequivocally negative answer. ${ }^{65}$ What is more, Lloyd George groundlessly claimed that the allies decided that Wilno would be given to Lithuania already at the time of the peace conference. "Wilno is not a Polish problem", he repeated ${ }^{66}$ (2) Without a thorough rethink of the potential consequences, the Polish government formally asked the Council of the League of Nations to mediate the dispute between Poland and Lithuania through Paderewski's letter of 5 September 1920, with the approval from Minister Sapieha, but with reservations from Piłsudski ${ }^{67}$ On the same day, the Council of the League undertook a mediatory mission. Poland - especially the opposition factors - considered turning to the League for mediation to be an error. ${ }^{68}$

On 21 September 1920, Askenazy explained reasons of the League's engagement in the Polish-Lithuanian dispute to Daszyński with its desire to achieve some spectacular success, which could be exploited to urge the United States to join the Geneva institution, on which "its whole future ultimately depended". It was then that a battle for the ratification of the Treaty of Versailles was taking place in the US Senate, eventually ending in its rejection. A Polish-Lithuanian settlement was therefore needed à tout prix. Askenazy believed that this circumstance could be used to take a hard line. On the other hand, however, there were signs of sympathy for Lithuania, "and partly also Sovdepia", mainly among the British delegates to the League. The position of France, hostile towards Poland, was influenced by factors of the "white" Russian emigration, "interested in denying Poland access to Lithuania and Wilno. This was the crux of the matter. Behind the Polish-Lithuanian issue stood the Polish-Russian issue", concluded Askenazy. ${ }^{69}$

In the wake of the military action of General Żeligowski, carried out by surprise on 9 October 1920, Poland took control of the disputed territory of Wilno and the Wilno region without armed resistance of the Lithuanian army. In Warsaw,

\footnotetext{
63 W. Grabski, Wspomnienia ze Spa, ed. S. Kirkor, London, 1973, p. 43.

64 Wandycz, Konferencja w Spa, p. 137.

65 Help was supposed to come if the Soviet troops would not stop at the Curzon Line (cf. W. Pobóg-Malinowski, Najnowsza historia polityczna Polski, vol. 2: 1914-1939, Gdańsk, 1990, p. 469).

${ }^{66}$ Cited from N. Davies, Lloyd George i Polska 1919-1920, Gdańsk, 2000, p. 30.

67 Sierpowski, Liga Narodów, pp. 87-90; K. Świtalski, Diariusz 1919-1935, ed. A. Garlicki and R. Świętek, Warszawa, 1992, pp. 110-111.

68 The delegate Skarbek attacked the Ministry of Foreign Affairs due to the lack of good instructions for the Polish delegation to the League: Protokoły Rady Obrony Państwa, pp. 305 and 310.

69 Raporty i informacje Biura Propagandy Zagranicznej, p. 84.
} 
the actions of Żeligowski's troops were presented as a "mutiny" and disobedience towards the Commander in Chief of the Polish armed forces..$^{70}$ In the new, changed conditions, Askenazy - following the instructions from the Polish government - undertook efforts for it to be recognised that the League's mediatory mission between Poland and Lithuania had been exhausted. However, he did not reach his aim, as he met opposition from Lord Balfour. The legal basis for the League's activities was the assertion from the representatives of the Allied powers that Poland had indeed passed the Wilno case into their hands at the conference in Spa, and had consented to its consideration at the conference in London. ${ }^{71}$

In the West, Polish actions of 9 October 1920 were widely condemned. The British stance was exceptionally negative. As a result, an idea appeared that Askenazy would travel to London in order to hold talks with British politicians and present the Polish viewpoint. It was believed, as the diplomat Jan Ciechanowski wrote to Paderewski from London, that in "some issues his sentence could have a positive impact". Żeligowski's action was interpreted as a violation of the solemn assertions made in Warsaw to the British envoy Sir Horace Rumbold. "The English government stands firmly in the position that if taking Wilno occurred, according to the Polish government, as a result of a wilful military movement, the Polish government will have to work very hard in order to consistently respond to this wilful action". ${ }^{72}$ During the session of the Council of the League, Askenazy and Lord Balfour clashed, as the latter argued that Poland violated the ceasefire declared two days earlier in Suwałki.

Żeligowski's action provoked unambiguously negative reactions of the French political circles, usually most favourable towards Poland. The President of the Council of the League of Nations Leon Bourgeois demanded an explanation from the Polish government, and expected an answer to his question "what steps the government has taken to eliminate Żeligowski's case. He demanded that the government declare its position in this matter". ${ }^{73}$ On 14 October 1920, Bourgeois directed a kind of ultimatum to Paderewski, stating that "if the army does not leave Wilno soon, the Council will be forced to hurriedly meet for the purpose of considering the position, which is believed to be serious". ${ }^{74}$ An exception among the French was General Maxime Weygand, who told the Polish liaison officer on the staff of Marshal Foch, Major Ludwik Hieronim Morstin, that he

70 On 6 December 1922, Piłsudski, as Head of State, accepting for the last time the Diplomatic Corps, deemed it appropriate to reveal that General Żeligowski acted on his orders (Tommasini, Odrodzenie Polski, pp. 21-215).

71 Wielhorski, Polska a Litwa, p. 339.

72 APP, vol. 2, pp. 517-518.

73 APP, vol. 2, p. 518. Paderewski's telegram to the Ministry of Foreign Affairs of 13 October 1920, in which he asked for information on the government's position regarding the Żeligowski operation.

74 Tommasini, Odrodzenie Polski, p. 215. 
would "not be in the least surprised if we wanted to forcefully finish the Lithuania business now, but that we have to count with the opinion of the world, and especially England". ${ }^{75}$

Of course, the authority of Piłsudski was involved in the case of Wilno, so there was no question of a withdrawal from the undertaking. At that time, he set himself the aim to "make the voice of Wilno an independent factor - not a new Żeligowski's mutiny, a masquerade, de facto backed by the Polish government. Let the international factors, if they want to, put pressure on Wilno, not on Poland" ${ }^{76}$ Polish diplomacy solicited an immediate truce between the Republic of Lithuania (the Kaunas Lithuania) and Central Lithuania. To this end, the Minister of Foreign Affairs demanded that "pressure from the League of Nations and allies be put on Lithuania", as otherwise an open armed conflict of the two countries, with all its consequences, would become inevitable. This, however, proved impossible. On 11 November 1920, Minister Sapieha wrote to his Paris envoy Maurycy Zamoyski: "Despite basically adopting the principle of consultation by Poland and Lithuania, the Lithuanian army continues to attack Żeligowski with the help of German volunteers, apparently inspired by the Germans. Żeligowski's position is increasingly difficult. The public indignation is enormous; unless an immediate ceasefire takes place, the government may find itself in a difficult position, because of the Sejm and the public opinion it may be forced to send an ultimatum to the government of Lithuania. We want to avoid this eventuality at all costs". ${ }^{77}$

An idea of a plebiscite on the territory affected by the conflict emerged as the most rational method of settling the Polish-Lithuanian dispute. On 28 October 1920 The Council of the League had already passed a resolution to hold a plebiscite in the disputed territories. ${ }^{78}$ However, on 25 November it was resolved that small international forces would be sent to the plebiscite territory and that it was necessary to remove Żeligowski's troops.

By a decision of the Council, the Civil Commission of the League was appointed, sent from Geneva to Kaunas and Wilno. At the same time, the Council of the League also established the Control Commission, headed by the French officer Colonel Pierre Auguste Chardigny. He knew Tsarist Russia and generally supported the thesis that Poland should not be given its way. His task was to "mediate between Polish and Lithuanian governments during negotiations about the territory on which the consultation [of the population] should be carried out". ${ }^{79}$ The most serious move of the Control Commission, on 17 December 1920, was to demarcate a neutral strip between the Republic of Lithuania and Central

75 Kukułka, Francja, p. 293.

76 Świtalski, Diariusz, p. 120.

77 APP, vol. 2, p. 559 (Zamoyski to Paderewski, 11 November 1920).

78 Łossowski, Po tej i tamtej stronie Niemna, p. 182.

79 Republic of Poland Delegation protocol of 1 December 1920, APP, vol. 2, p. 584. 
Lithuania in order to separate the sides of the conflict, 5-12 kilometres wide, and about 150 kilometres long. ${ }^{80}$ This strip would only be removed by a resolution of the Council of Ambassadors from 3 February 1923.

When deciding to send in troops, the Council requested that the costs of transport and food be covered by the sides of the ongoing dispute "in a proportion to be decided after the territories are distributed". Basic costs would be paid by the countries sending troops. ${ }^{81}$

When suggesting the plebiscite, Lord Balfour categorically demanded the removal of Żeligowski's troops; Askenazy replied, however, that these forces are "a local element". ${ }^{82}$ The Polish government expressed acceptance for holding the plebiscite and sending international troops, putting forward the need to act immediately. It also reserved the right to sovereign assessment of the conditions of the proposed plebiscite. These conditions were detailed by the letter from Paderewski and Askenazy to Bourgeois. ${ }^{83}$

On orders from the Ministry of Foreign Affairs, Askenazy stressed this in the note to Bourgeois of 11 December 1920: "La solution la plus rapide du problème des territoires de consultation s'impose comme le seul moyen efficace de consolider les conditions économiques et sociales de ces territoires déjà si rudement atteint par la guerre et par les récentes épreuves". ${ }^{44}$ The position of the government agreed in principle with the beliefs of the main directions of the central and left wing Polish public opinion. Kurier Poranny wrote on 28 October 1920 that "our minister plenipotentiary, Askenazy, was right to adopt the principle of self-determination as the basis on which stood the government of the Republic of Poland, from the time of Piłsudski's noble and wise Wilno address, declared that the Polish government must evaluate the details of the system in which the self-determination should be carried out". ${ }^{85}$ The right-wing national camp had a different view on the issue. Radical arguments were often raised, pointing out that Żeligowski's actions were an unnecessary move, because the Kaunas Lithuania should have been annexed, as it were, "on the occasion" of chasing after the defeated Soviet army.

As a delegate of the Republic of Poland, Askenazy received the order to take action so that the plebiscite would not be organised in Grodno, an indisputably Polish territory. ${ }^{86}$ Demanding that Grodno be excluded was based on military and strategic considerations. Only based on controlling this city did it seem possible to plan an offensive manoeuvre in any defensive war against Russia, and its loss

${ }^{80}$ H. Wisner, Litwa. Dzieje państwa i narodu, Warszawa, 1999, p. 179.

81 APP, vol. 2, p. 583. Askenazy's telegram to Sapieha on 1 December 1920 (The League had no armed forces of its own).

${ }^{82}$ Nowak-Kiełbikowa, Polska - Wielka Brytania, p. 272.

${ }^{83}$ APP, vol. 2, p. 555.

${ }^{84}$ Ibid., p. 603.

${ }^{85}$ Raporty i informacje Biura Propagandy Zagranicznej, p. 375 (annexes).

86 APP, vol. 2, p. 581. 
would make this impossible, as shown by the events of 1920. In the minutes of the proceedings of the Polish delegation at the League, Grodno was called "a fortress, dominating the strategic lines that are important for us". ${ }^{87}$

The General Secretariat of the League was not well versed in the historical, linguistic and geographic realities of the lands where the plebiscite was to be held. "The historical exposé on Lithuania, published by the General Secretariat of the League following Lithuania's request to join the League of Nations, contains a series of inaccuracies, namely the mentions of the division of Lithuania among Germany, Russia and Austria, and the Lithuanian national uprisings in 1831 and 1863". In this situation, Askenazy, as a historian, was entrusted to write a "semi-formal letter to the General Secretariat of the League", in which he was to "point out these errors".

With a weak hand in the diplomatic game with Poland, Prime Minister Voldemaras tried to pull Soviet Russia into consultations around the PolishLithuanian conflict. Askenazy deemed this to be an attempt to "intimidate the Council", supposedly met with "indignation of the Council, especially Bourgeois and Balfour" ${ }^{88}$ Opposed to sending Allied forces to protect the plebiscite, the Soviet Government made a formal protest and announced that it would take retaliatory steps ${ }^{89}$ From the point of view of the Council of the League, this was a harbinger of serious complications, although it does not seem likely that Soviets would put their threats into practice, given their country's exhaustion following the civil war and losing the war with Poland. In any case, the objection of the Soviets affected the opinions in Western countries.

However, introducing a Soviet factor complicated the situation. Sending coalition troops was severely hampered. The Council of the League could not muster "any resolutions". Colonel Chardigny was expected to explain "whether coalition troops would indeed be in danger from the Soviets, and whether the government in Kaunas wishes to prevent the consultation, or is resorting to blackmail". ${ }^{90}$

On 18 December 1920, The Council of the League of Nations, on a conciliatory mission in the Polish-Lithuanian dispute, passed a new resolution to carry out a plebiscite under the auspices of the League on the territory for which both sides were fighting. Voting safety was to be guaranteed in the form of international troops. The Council's resolution called on the Polish government to "use all measures it deems necessary to seek disarmament, dissolution or withdrawal of General Żeligowski's troops". Its text also contained reservations claiming that the League of Nations would "never accept a plebiscite carried out under conditions that would not give sufficient guarantees to all concerned". ${ }^{91}$ The demands of the

${ }^{87}$ Ibid., p. 585.

${ }^{88}$ Ibid., pp. 599-601 (report from 9 December 1920).

89 Wielhorski, Polska a Litwa, p. 340.

${ }^{90}$ APP, vol. 2, p. 600.

91 Ibid., pp. 614-615 (report from 27 December 1920). 
Council of the League took the form of an ultimatum, as the Polish government was given ten days to respond. The expected answer was submitted by Paderewski and Askenazy within the required period of time.

However, fearing complications, on 2 March 1921 the Council of the League of Nations de facto withdrew from the idea of a plebiscite. It vaguely indicated the difficulties in implementing the resolution, posed by "both representatives of the states concerned". ${ }^{92}$ It is possible that this was decided not so much by the fear of Soviet Russia, but rather by the reluctance to interfere in the fate of the lands constituting the territory of pre-revolutionary Russia, whose restoration was still believed in, especially in Paris. ${ }^{93}$

A new proposal came from the Council of the League: to cancel the plebiscite and commence direct Polish-Lithuanian talks regarding Wilno. Because Poland submitted an offer to return Wilno at the price of establishing a legal and constitutional bond between Poland and Lithuania, the League of Nations showed interest in the concept and offered their new bons offices. The Council of the League determined that Brussels would become the place of the PolishLithuanian talks. In this way, the proposal of the Lithuanian government to hold negotiations in London fell through, as did the Polish suggestion for the talks to take place in Kaunas. ${ }^{94}$ The reporter and mediator was the Belgian Minister of Foreign Affairs, Paul Hymans. ${ }^{95} \mathrm{He}$ was aware of the difficulty of his mission from the very start. "Ma situation sera donc très délicate", he wrote to the ambassadors of three Allied powers in Brussels. ${ }^{96}$

The Polish government agreed to the proposed solution. In the face of the mediation offer from the League of Nations, Polish concessions proved necessary. On 12 March 1921, Piłsudski concluded that "we must agree to remove Żeligowski". He was also considering recognising the Republic of Lithuania de iure, which Poland had failed to do until then. Bearing in mind the new situation, the Marshal believed the most important thing was not to ignore the will of the population of the so-called Republic of Central Lithuania in the decisions concerning the state affiliation of these lands, regardless of whether the decisions would be "internationally sanctioned" or not. He also demanded that this was mentioned in the letter from the Polish Government to Żeligowski, and in the statement accepting Brussels negotiations. ${ }^{97}$ On 13 March 1921, in a conversation with Askenazy,

92 Wielhorski, Polska a Litwa, p. 341.

93 Anti-Soviet rebellion in Kronstadt in March 1921 could have favoured the convictions about the near end of Bolshevism.

${ }^{94}$ Instructions of the Ministry of Foreign Affairs for the delegation in London from 2 February 1921, PISM, Embassy of the Republic of Poland in London, cat. no. A.12.53/45.

95 His own diary accounts on these issues - see P. Hymans, Mémoires, Bruxelles, 1958, vol. 1.

${ }^{96}$ Letter of 25 May 1921, Archives de la Société des Nations (Geneva), Fonds du Sécretariat Général. Section Politique (hereinafter: SG-SP), cat. no. R. 588/11/13343.

97 Świtalski, Diariusz, pp. 78-79. 
Piłsudski expressed an opinion that "Lithuanians won a lot. They are counting on the fact they can force Poland to do many things [...]". ${ }^{98}$

The Brussels talks promised to be very difficult. Lithuania's last offer addressed to Poland, from 23 December 1920, did not create conditions for a compromise. The government of the Republic of Lithuania set the following conditions for settling the dispute with Poland: (1) Poland was to consider Lithuania de iure; (2) Lithuanian borders and the provisions of the Lithuanian-Soviet treaty of 12 July 1920, giving Wilno and the Wilno region to Lithuania, were to be confirmed; (3) Lithuania would take on "a commitment to remain neutral" and grant Poland free transit through its territory; (4) the Lithuanian government offered constitutional guarantees of "equality for all nationalities", including "personal autonomy" for Poles, "decentralisation of the internal regime, using the majority language in most state institutions on an equal footing with Lithuanian state language"; (5) the Lithuanian government also offered "amnesty" to imprisoned Poles. Once these conditions were accepted, the Polish troops in the so-called Central Lithuania would be withdrawn, and the Wilno region incorporated into the Republic of Lithuania. The disputed territory would hold elections to the Sejm in Kaunas, with the supervision of the Control Commission. Wilno would become the "capital of the united Lithuania". ${ }^{99}$ The Minister of Foreign Affairs Sapieha deemed the presented terms insufficient, but on the same day (23 December 1920) gave instructions to respond to the government of Lithuania that he acknowledges these proposals. $\mathrm{He}$ stressed the need to keep Polish obligations towards the population of the Wilno region, who "should be allowed to express their will". He also declared that Poland would be happy to enter into "a covenant with the Kaunas Lithuania", leaving the decision about the fate of the "disputed territories to the population". ${ }^{100}$

When deciding to negotiate in Brussels, Poland could not count on the support of the British envoy at the League of Nations, Lord Cecil, nor the French one, Bourgeois. Also Italy kept its distance from the Wilno issue, raising scepticism regarding the possibility of a Polish-Lithuanian federation. ${ }^{101}$ On the other hand, there was hope in Paul Hymans, a Belgian socialist, appointed first the President of the League of Nations commission for Polish-Lithuanian matters, then Chairman of the Brussels Conference. Paderewski described him as "a friend of Poland" ${ }^{102}$

The Brussels Conference lasted from 20 April to 3 June 1921. In reality, negotiations began on 2 May.

The main representative of Poland in the negotiations was Askenazy. Alongside him, the Polish delegation comprised members appointed by the Ministry of Foreign Affairs: Mirosław Arciszewski (later an envoy in Bucharest and Deputy Secretary

98 Ibid.

99 APP, vol. 2, p. 614.

100 Ibid.

101 S. Sierpowski, Stosunki polsko-włoskie w latach 1918-1940, Warszawa, 1975, pp. 79-80.

102 Paderewski to Sapieha, 22 September 1920, APP, vol. 2, p. 498. 
of State), Juliusz Łukasiewicz (later the director of the Political Department of the Ministry of Foreign Affairs as well as the ambassador in Moscow and Paris), and Anatol Mühlstein. ${ }^{103}$ Only Askenazy and Łukasiewicz had the status of delegates. Piłsudski's letter of appointment for the Brussels delegation is dated 13 April 1921. ${ }^{104}$

We should also mention that Major Józef Beck, later a military attaché in Paris and Brussels as well as the Minister of Foreign Affairs of the Republic of Poland (1932-1939), received the function of a military expert and, it is believed, was to "keep an eye on Askenazy". ${ }^{105}$ This surely shows that Piłsudski did not trust him fully.

The president of the Lithuanian delegation to Brussels, Ernestas Galvanauskas, who replaced Voldemaras, was the incumbent Prime Minister and the Minister of Foreign Affairs of his country. ${ }^{106}$ Lithuanian representatives were therefore at a higher formal position than the Polish one. It also comprised the diplomats Jurgutis, Petras Klimas, Oskaras Milašius (Oscar Milosz), Narusevicius, Mykolas Sleževičius, Soloveičikas and the military expert Colonel Konstantinas Kleščinskas. Oscar de Lubicz Milosz (Oskaras Milašius), a professor at the Sorbonne, was a well-known poet who wrote in French and resided in Fontainebleau, near Paris. "This cosmopolite felt a strong nostalgia for his homeland", Czesław Miłosz wrote about him in his glossaries to a Polish translation of Milašius' selected poems. ${ }^{107}$ He was part of the Lithuanian delegation to the League of Nations, and would then be appointed as an envoy in Paris. According to Czesław Miłosz, he allegedly did not accept the position of the Minister of Foreign Affairs he was offered. He learned the Lithuanian language "like many Lithuanians, be browsing through dictionaries". With Professor Askenazy "he argued in Polish. But he wrote only in French and was deeply attached to France". ${ }^{108}$

The League delegated a team led by the Secretary-General Eric Drummond. In addition, it included the French diplomat Paul Mantoux (head of the Political Section in the General Secretariat), Ernest Denis (French slavist and professor), Colonel Chardigny, General Burt and the diplomat Naze.

The Lithuanian delegation set itself a clear task in the negotiations. In a memorandum to the League of Nations from 4 May 1921, it demanded two things: recognising Lithuanian independence and sovereignty over Wilno and the Wilno region, instead offering autonomy to the Polish population ("Polish-language citizens of the

\footnotetext{
${ }_{103}$ Wisner, Wojna nie wojna, p. 152. The author does not mention Mühlstein.

104 SG-SP, cat. no. R. 588/11/13575.

105 Cf. M. Kornat, "Józef Beck - zarys biografii politycznej (1894-1932)", Niepodległość 55 (35 after reprint), 2005, p. 58.

106 Lietuviu Enciklopedija/Lithuanian Encyclopaedia/Encyclopedie Lithuanienne, vol. 6, Boston, 1955, p. 503.

107 O.V. de L. Miłosz, Wybór poezji, ed. M. Leśniewska, Kraków and Wrocław, 1983, p. 210.

108 Milosz, Wybór poezji, p. 211. Cf. also J. Bardach, "Opcja litewska Oskara W. Miłosza”, in: id., O dawnej i niedawnej Litwie, pp. 353-379.
} 
Republic of Lithuania") as well as the trade agreement based on the principle of a mutual most favoured nation clause. The demands were accompanied by a request for Poland to fully recognise Lithuanian sovereignty in Klaipeda, if it was given to Lithuania. ${ }^{109}$ In other words, it was a repetition of the Lithuanian memorandum of 23 December 1920. In the field of political relations, Lithuanians did not see any need apart from declaring compliance with the principle of non-aggression in mutual relations, demanding the same from Poland. Askenazy considered this offer unacceptable. ${ }^{110}$ He stated that the liberation of Wilno was accomplished at the cost of Polish blood in the battles with the Soviets. He also repeated a known Polish claim about the people's right to self-determination, in accordance with the address of the Chief of State to the inhabitants of the former Grand Duchy of Lithuania on 22 April 1919. ${ }^{111}$

Leaving Warsaw at the end of April 1921, Askenazy told the French envoy de Panafieu that he would do everything in his power to reach an agreement with Lithuania. He stressed that he felt "a great responsibility for the future placed in his hands", as he was aware that during these talks Witos would submit his resignation and a long cabinet crisis was likely in Warsaw, and political parties were not sympathetic towards the idea of a federation with Lithuania. ${ }^{12}$ Let us add that in the spring of 1921 the rumours of an imminent resignation of Witos (the recent Prime Minister of the National Defence Government) were on the rise.

Askenazy went first to Geneva, which was mentioned in a letter to Drummond by his deputy, Paul Mantoux. ${ }^{113}$ From there he travelled to Brussels.

The Polish draft agreement, drawn up by the Minister Sapieha and protested by the National Democracy party, proclaimed the need to establish (or resume) a Polish-Lithuanian union. A joint state entity would have a common president, elected by the combined Lithuanian canton Sejms and the Polish Sejm. Common issues would be selected: foreign policy, defence, economic affairs (customs) and communication matters. Reserved common issues would be jointly decided by representatives of the parliamentary assemblies of both states. Offices would be appointed for a common Minister of Foreign Affairs, common Minister of War, and a common office for economic and communication affairs. In the event of war, command of the joint armed forces would be reserved for a representative of the Polish Army. Military cooperation would be regulated by an army convention.

109 SG-SP, memorandum cat. no. R. 588/11/12592.

110 P. Łossowski, Stosunki polsko-litewskie 1921-1939, Warszawa, 1997, pp. 12-13.

111 Cf. on this issue: W. Suleja, "Geneza odezwy Naczelnika Państwa do mieszkańców byłego Wielkiego Księstwa Litewskiego z kwietnia 1919”, Niepodległość 25 (1992), pp. 6-22. It is misleading to see Piłsudski as a federalist - Paderewski was more of a federalist. Piłsudski was not interested in regime experiments, but in geopolitical reconstruction of Eastern Europe in line with the Polish state interest - in the name of building an as strong as possible "neutral zone" between Germany and Russia.

112 Telegram from de Panafieu at Quai d'Orsay (copy), 29 April 1921, SG-SP, cat. no. R. 588/11/12128.

113 Letter of 21 April 1921, SG-SP, cat. no. R. 588/11/12307. 
Poland placed a decisive emphasis on introducing a Lithuanian-Polish military alliance, of particular importance for Józef Piłsudski. His trusted representative, Major Beck expressed the position of the Polish Chief of State when pointing to "the need to establish a joint defence plan; the need to predict joint command, which can only be Polish. During the war, Lithuania and Poland are to be treated as a common territory, where Polish troops should be used. Indeed, it is impossible to organise the defence of each of the two countries, according to a purely territorial system. An agreement is necessary to prepare for a war, weapons must be standardised in order to make supply easier. In the same way, training and organising troops should take place in accordance with uniform rules. Finally, the convention should provide for rail improvements, better communication between railway lines and, perhaps, fortifications". ${ }^{114}$ Assumptions were also developed for a future Polish-Lithuanian convention.

With such essential differences of positions, there was no chance of reaching an agreement. In any case, Galvanauskas used every opportunity to highlight the discrepancies. For instance, he talked about the need to revise the Treaty of Riga, signed on 18 March 1921, if Bolshevism collapsed in Russia.

Already at the first session on 2 May 1921, Askenazy declared that he recognised "absolute equality of the sides". ${ }^{115} \mathrm{He}$ also put forward the idea of separating the Wilno issue from the issue of general regulation of a state relation of Poland to Lithuania, and vice versa.

On 13 May 1921, a common foreign policy was debated. Hymans saw two possibilities in the case of establishing a Polish-Lithuanian state: either a common Ministry of Foreign Affairs would be created, or a joint permanent conference, consisting of two delegations, would be in operation.

A week later, on 20 May, Hymans drew up his first (initial) project. His guiding idea was to be "ensuring a rapprochement between the two countries, which does not entail forming a federation, but a closest possible union, reconcilable with sovereignty and independence of each". ${ }^{116}$ The author of this concept imagined that it would become the basis for specific Polish-Lithuanian talks. He did, of course, permit its modifications.

First of all, an obligation would be imposed Lithuania to create a federation binding two cantons: Kaunas and Wilno. ${ }^{117}$ In a state thus organised, there would be two obligatory languages: Lithuanian and Polish. Comprising these two cantons,

114 Minutes from a conversation between Beck and Chardigny from before 7 July 1921, JPIA, GACC, no. 41/3.

115 Documents diplomatiques concernant les relations polono-lithuaniennes, vol. 1, Varsovie, 1921, p. 6.

116 Tommasini, Odrodzenie Polski, p. 219.

117 The concept of cantons corresponded with the postulates of Polish advocates of the reconstruction of a multinational Lithuania. Cf. Bardach, Projekty organizacji kantonalnej Litwy, pp. 280-292. 
the Lithuanian state would join a union with Poland. Joint state institutions would be appointed: (1) a Common Council for Foreign Affairs with six members - three delegates selected by each Sejm; (2) Common Chief Command in the case of war, by agreement of the General Staffs; (3) Economic Council. Poland was to receive free transit of goods through the territory of Lithuania. A trade agreement would also be signed. The Council of the League of Nations was to appoint an arbiter to settle disputes between the two sides.

Genesis of Hymans' first plan is not easy to recreate. Juliusz Bardach indicated that it had been invented by minister Sapieha, and inspired the Belgian politician with the idea, acting through the French and arguing that Lithuania must be bound to Poland, as sooner or later it would fall under the influence of Germany. On the other hand, the well-known Lithuanian diplomat Sidzikauskas claimed that the author of the plan, however, was Hymans himself.

We should note that the canton system designed for Lithuania seemed coherent, but lacked a common constitutional act - which was immediately noted by an insightful observer and an envoy in Warsaw, Francesco Tommasini, who wrote that "the most important point was the lack of any permanent constitutional node between the two states, while it was widely known that Lithuanian policies were in fact opposed to Polish policies. Under these conditions, it was easy to predict that the common authorities, without any substantial power, from the very beginning would be brought to a total or near-total powerlessness". ${ }^{118}$

Hymans' first project was called by the Polish historian Piotr Łossowski "a notable attempt to provide a general solution for the dispute". ${ }^{119}$ Askenazy expressed immediate agreement to Hymans' proposals, but seven days later added a reservation that it is necessary to respect the will of the population of Wilno and the Wilno region. ${ }^{120}$ The Lithuanian side did not accept these proposals as a basis for further works.

The key talks were held between 23 and 28 May. They yielded only controversy and presenting divergent positions. On 25 May Askenazy proposed the submission of the positions in writing. ${ }^{121}$ The Polish side was the first to do so. In a separate memorandum, dated 29 May 1921, Poland accused the government of Lithuania of wanting to decide the fate of Wilno and the Wilno region without taking into account the will of its population. On 30 May 1921 the Lithuanians upheld their conditions by adding - seemingly as a concession - that they were ready to enter into a special arrangement with the League of Nations, within the international system for the protection of national minorities, which would grant

118 Tommasini, Odrodzenie Polski, p. 220.

119 Łossowski, Stosunki polsko-litewskie, p. 15.

120 A.M. Cienciała, T. Komarnicki, From Versailles to Locarno. Keys to Polish Foreign Policy 19191925, Kansas University Press, 1984, p. 144.

121 Documents diplomatiques, pp. 92-104. 
cultural autonomy to the Polish-language citizens of Wilno and the Wilno region. ${ }^{122}$ For the Polish side, this solution was not sufficient.

On 7 June Hymans wrote in a note to Drummond expressing the hope that the governments of Great Britain, France and Italy would provide diplomatic support in Warsaw to the idea of accepting his project. ${ }^{123}$ However, Poland was not critical to the success of the talks, into which Hymans had put a lot of effort, but rather Lithuania.

"Our relationship with Lithuania", said Piłsudski, "can be determined by deleting the line of German trenches and an agreement with Lithuania: a) either ethnographic Lithuania and Wilno for Poland, b) or Lithuanian-Polish Lithuania with Kaunas and Wilno, and an alliance between Poland and Lithuania". ${ }^{124} \mathrm{We}$ can notice that the second alternative converged with the guiding principle of Hymans' first project.

On 22 May 1921, the Marshal expressed an opinion to his colleagues that "recognition of the equivalent [position] of the Kaunas Lithuania and Wilno Lithuania, contained in Hymans' projects, allows all to state specifically that Lithuania as a finished state entity does not yet exist. Our guiding principle must be preventing the creation of a Baltic union, before settling the matter of our relation to Lithuania". ${ }^{125}$ In these conditions, Piłsudski believed that "Askenazy is unnecessarily impatient and wants to make concessions. We should calmly wait until autumn, when we will be protected from an attack by Russia, and when our situation will be much stronger. Lithuanians will then hurry, because the current situation favours us more". ${ }^{126}$ Perhaps these words mean that the Marshal still thought it possible that Lithuania might change its position in the future. It is also possible that he was considering future negotiations from a position of strength.

In June 1921, Piłsudski believed that the federal union of Lithuanian cantons with Poland would benefit England. He was even guided by the idea of strengthening Lithuania, if it was to accept the federal solution. On 27 June 1921, he told Kazimierz Switalski that "if a federation of Poland and the Kaunas Lithuania is fully executed, we can then talk about giving a Latvian corridor to Great Lithuania. The English liked the thought very much, as they are counting on it to expand their transit zone to Russia". ${ }^{127}$ As late as in November 1921, Piłsudski was inclined to believe that Lithuania could accept Hymans' first project. "The Commander senses - noted Świtalski - that the Kaunas Lithuania, unless it undertakes a military action at the news of elections to the Assembly of Wilno, will agree to Hymans'

\footnotetext{
122 Łossowski, Stosunki polsko-litewskie, p. 17.

123 SG-SP, cat. no. R. 588/11/13282.

124 W. Baranowski, Rozmowy z Piłsudskim 1916-1931, Warszawa, 1938, p. 137.

125 Świtalski, Diariusz, p. 84.

126 Ibid., p. 86. Statement of 20 June 1921.

127 Ibid., p. 91.
} 
project". ${ }^{128}$ When in September 1921 Poland voted against accepting Lithuania to the League of Nations, Piłsudski considered this an error.

It is true that Piłsudski was critical of Askenazy's tactics in Brussels, seeing in it a tendency to making excessive concessions. ${ }^{129}$ At the suggestion of the delegate at the League of Nations, the foreign minister Skirmunt allegedly considered some concessions on the issue of Central Lithuania administration, but Piłsudski was opposed, and in negotiations with the Allied powers demanded taking into account the will of the population of the Wilno region. ${ }^{130}$ Askenazy's work was also criticised in the press, claiming that "promoting the federation idea in the issue of Lithuania" was taking place "despite clear declarations of the government" and led "to depreciating our authority in the international world". 131 The articles of Professor Stanisław Stroński particularly stood out, written against the Brussels negotiations, and using accusations that the Brussels concessions had been a disgrace and a defeat of the Polish diplomacy. ${ }^{132}$

On 1 June 1921, Askenazy spoke openly that the Polish delegation had not achieved any positive results. He emphasised that the right of the people of Wilno and the Wilno region to self-governing remained an unquestionable principle of Polish politics. ${ }^{133}$

When the Brussels negotiations failed, on 28 June 1921 the Council of the League adopted a new resolution on continuation of the Polish-Lithuanian talks, to which the Polish government responded positively, with a note on 15 July. However, it set a condition that any adjustment of the situation of Central Lithuania must be approved by the Sejm of the country which was to be selected to represent the will of its population. The Polish position assumed that Hymans' first project was acceptable; for Lithuanians it was not. Of course, Polish diplomacy planned to make efforts to have the project amended in a more favourable spirit towards Poland. On 18 August 1921, Askenazy received instructions from the Ministry of Foreign Affairs, stating that "we should first of all do our best, so that Mr. Hymans' [final] report is to our benefit, and is adopted by the Council without debate and new resolutions". ${ }^{134}$ These instructions show concerns that Hymans' project may still be adjusted by the Council of the League, and after the possible negotiation of the final Lithuanian-Polish agreement, that the League may not limit itself only to its formal acceptance.

128 Ibid., p. 110. Pilsudski's statement of 26 November 1921. The Marshal probably had in mind Hymans' second project.

129 Świtalski, Diariusz, pp. 91-94. Cf. also W. Jędrzejewicz, J. Cisek, Kalendarium życia Józefa Piłsudskiego 1867-1935, vol. 2: 1916-1920, Łomianki and Kraków, 2006, p. 253.

130 Świtalski, Diariusz, pp. 87-88.

131 Gazeta Poranna on 10 December 1920; cf. Raporty i informacje Biura Propagandy Zagranicznej, p. 387.

132 Wisner, Wojna nie wojna, p. 152.

133 SG-SP, cat. no. R. 588/11/12307.

134 Łossowski, Stosunki polsko-litewskie, p. 19. 
In a letter of 14 August 1921, Minister Konstanty Skirmunt informed Hymans that he entitles Askenazy to arrive in Geneva on 25 August. He mentioned that the Polish government regretted Lithuania's negative response to the Council of the League's resolution of 28 June. The letter from the Polish Minister of Foreign Affairs also included a statement that "the conflict with Poland does not reflect the Lithuanian nation's true aspirations". ${ }^{135}$

"Hymans' project, adopted by us as a basis for discussion, requires extending in many directions for the interests of Poland, and complementing with necessary legal and state guarantees. Our politics will move along this line, if Hymans' action does not fall apart altogether. If the whole negotiations collapse, our attempts should aim at gradually getting the Allied powers accustomed to the idea of the Wilno region existing as a separate entity, autonomous in the broadest sense, however, I believe, with close bonds with Poland", wrote Władysław Wróblewski, an envoy in London, in a report for Minister Skirmunt on 27 August 1921. ${ }^{136}$ In these words, we can notice the idea of correcting Hymans' first project in order to safeguard the interests of Poland. Lithuanian perspective was entirely different - the government in Kaunas was interested in weakening the project as much as possible, in order to thwart the idea of a confederation. The offer of autonomy for Wilno within the Republic of Lithuania was the only and the largest Lithuanian concession it declared.

Guided undoubtedly by his desire to face Lithuania's concerns, on 3 September 1921 Hymans presented the second project. ${ }^{137}$ Its essence came down to the idea of giving Wilno and the Wilno region autonomy within the Republic of Lithuania. It failed to mention an issue fundamental for Poland, that of establishing a state union with Lithuania. As a result, Poland rejected the proposed solution. It was also rejected by Lithuania, by a decision of its government from 24 December 1921. Lithuanians "demanded exclusivity of its power and culture" on the territory of Wilno and the Wilno region. ${ }^{138}$ "Kościuszko's Lithuania no longer exists", declared Oscar Milosz (Oskaras Milašius) at one of the meetings of the Brussels Conference. ${ }^{139}$

In September 1921, Askenazy was still attempting to bring about a return to Hymans' first project - but to no avail. ${ }^{140}$

On 9 September, the Polish envoy to the Brussels negotiations wrote to Hymans, declaring openly that representatives of the population of Wilno and the Wilno region would gather, and that the Lithuanian claims that the will of

\footnotetext{
135 SG-SP, cat. no. R. 588/11/14729.

136 PISM, Embassy of the Republic of Poland in London, cat. no. A.12.49/3.

137 Łossowski discusses this issue, Po tej $i$ tamtej stronie Niemna, pp. 191-195.

138 Wielhorski, Polska a Litwa, p. 343.

139 O.V. de L. Milosz, Deux messianismes politiques, précédé de Vilna et la civilisation Européenne, l'alliance des états baltiques, l'emprise allemande sur la Russie, Paris, 1990, p. 180.

${ }^{140}$ Nowak-Kiełbikowa, Polska - Wielka Brytania, p. 346.
} 
the population would be "imposed from Warsaw", were totally unfounded. "From the moment of liberating Wilno from the hands of Bolsheviks three years ago, the Polish government has not paused in its efforts to prove, through declarations and actions, that it respects the will of the population as a fundamental basis for determining its future. It has [also] never intended to act violently against the will of one million free people". ${ }^{141}$ Let us mention that this statement remains a veiled polemic with Hymans' argument, contained in his earlier letter to Askenazy, in which he had described the actions of Poland towards Wilno as "dictated or tolerated by the Polish government" and "contraires aux engagement moraux pris par celui-ci vis-à-vis de la Société des Nations". ${ }^{142}$

At the same time - in a letter to Hymans dated 13 September - Askenazy maintained the position of the Polish government, expressing willingness to hold talks on the basis of the Council's resolution of 28 June to approve the "projet transnational of 20 May 1921". ${ }^{43}$ However, this did not mean Poland's unconditional agreement to the text of the confederation project of 20 May 1921, on which Hymans insisted in a conversation with Askenazy on 30 August. It was only his acceptance as a basis for discussion with the government of Lithuania. ${ }^{144}$

An interesting report was created at the end of September by the British envoy William Max Muller for Curzon. He claimed that the Minister of Foreign Affairs, Skirmunt, and other officials of the Ministry in Warsaw are not pleased with Askenazy's uncompromising position in Geneva. Although his action against Hymans' second project seemed understandable, claims against the recognition of Lithuania as a state did not. Askenazy worked without instructions, and was "tactless and purposeless, though it is now too late to disavow it", claimed the British diplomat. ${ }^{145}$ However, he ended his report with an opinion that convincing Poles to accept Hymans' second project was not possible, since they considered the first one to be right. The accuracy of the information, or rather the rumours reported by Max Muller, is not possible to verify.

The British Ambassador in Paris, Lord Hardinge, after a conversation with Jules Laroche, the then Secretary of State on the Quai d'Orsay (later Ambassador to Warsaw), drew a simple conclusion: that Lithuanians agreed to talks with Poles in order to force Poland to withdraw Żeligowski's troops from Wilno and the Wilno region by means of diplomacy. At the same time, Laroche noted that forcing Poland to do so is simply impossible. ${ }^{146}$ It should be noted that both these statements remain true.

141 SG-SP, cat. no. R. 588/11/15688.

142 Ibid.

143 SG-SP, cat. no. R. 589/11/15751.

144 Ibid. Letter from Askenazy to Hymans of 12 September 1921.

145 Report from 24 September 1921, TNA, Foreign Office 371, 8604, N.10775/44/55.

146 TNA, Foreign Office 371, 6804, N. 10991/44/55. Lord Hardinge (Paris) to Lord Curzon, report of 30 September 1921. 
On 24 September, the Council of the League took under consideration the final reports from the Brussels talks and thanked Hymans for his efforts. ${ }^{147}$ Seven days later the Belgian politician announced to all the members of the Council that his mission was over. "Il parait inutile de poursuivre les pourparlers après la dernière decision du Conseil", he wrote in the statement. ${ }^{148}$

The Brussels talks, especially in their second stage, provoked a number of negative reactions in Poland. The press launched an attack on Skirmunt for his conciliatory approach, including National Democracy newspapers, even though he came from the diplomatic ranks of the Polish National Committee. A spiteful opinion emerged according to which he "obeys the will of foreign ambassadors, as he once obeyed the Governor-General" of Russia when he took part in the unveiling of the monument to Catherine II in Wilno in 1903. The Minister of Foreign Affairs was accused of remaining united with Askenazy - as the German chargé d'affaires in Warsaw, Schoen, reported to Berlin. ${ }^{149}$

In the face of failed negotiations in the capital of Belgium, Poland began to consider a unilateral solution - its own plebiscite on the contested territory, and then taking the steps to obtain sanctions for this solution from the international community. With this scenario in mind, on 14 December 1921 Piłsudski, when receiving Askenazy at an audience, ordered him to fight for a League of Nations delegation to be sent to Wilno, or for the Wilno Assembly to be called to Geneva, when it is elected. ${ }^{150}$ Askenazy received instructions to take efforts to obtain a mandate for Poland from the allies to "politically organise Central Lithuania". ${ }^{151}$ These efforts could not bring results, as the British categorically demanded the withdrawal of Żeligowski's troops as a condition sine qua non for any talks.

Askenazy, according to Świtalski's Diariusz was opposed to repressive steps in Central Lithuania, taken against Lithuanian national activists by the Interim Governing Committee. This refers to Lithuanian oppositionists in Central Lithuania led by Mykolas Biržiška, who were to be arrested as spies. ${ }^{152}$ This put Askenazy in a difficult situation. ${ }^{153} \mathrm{He}$ asked the Chief of State to intervene. "Askenazy was the initiator of the action against the arrest of Biržiška and his companions. He fears that it may cause a new interference in the Wilno issue by the League of Nations, which may send some commission", Świtalski noted on 31 January $1922 .{ }^{154}$

\footnotetext{
147 SG-SP, cat. no. R. 589/11/16383.

148 Ibid.

149 Politisches Archiv des Auswärtigen Amtes (Berlin), Botschaft Warschau, box 20, Bd. 2: 19211922 (report for the Foreign Minister from the Reich of 19 November 1921).

150 Jędrzejewicz, Cisek, Kalendarium życia Józefa Piłsudskiego, vol. 2, p. 272.

151 Nowak-Kiełbikowa, Polska - Wielka Brytania, p. 343.

152 Świtalski, Diariusz 1919-1935, pp. 124-127.

153 Łossowski, Stosunki polsko-litewskie, p. 30.

154 Świtalski, Diariusz, p. 128.
} 
Askenazy was warned against repressive actions by a French envoy in Warsaw, Hector de Panafieu, who said that "the arrests are a suicidal policy". ${ }^{155}$ In response, "the Commander gave instructions that if there is evidence to convict Biržiška and his comrades for military espionage, they should be kept in prison, as impunity is a bad thing. If there is no such evidence, it is better to send them to Kaunas". 156 At this point it is worth mentioning that the instructions were executed, as soon after the elections to the Wilno Ruling Sejm, on 4 February 1921, thirty-three detained activists were deported to Lithuania by order of the President of the Interim Governing Committee, Aleksander Meysztowicz.

In December 1921, Piłsudski concluded that he knew of "no international acts that would prohibit Poland to annex the Wilno region, with the consent of its population". ${ }^{157}$ Askenazy saw this as a more complex matter. At a meeting of the Political Committee of the Council of Ministers on 7 February 1922, Askenazy reported on the Wilno and Wilno region issue "from the point of view of international politics". He stressed that "Poland is dependent on great powers in terms of this solution, in accordance with art. 87 of the Treaty of Versailles, on Russia in accordance with the Treaty of Riga, which does not determine the fate of Wilno region but refers the matter to Poland and Lithuania's attention, and on the League of Nations, to which Poland passed on the issue in 1920". Askenazy pointed out that "great powers unanimously indicate the need to resolve the Wilno issue in a way that will not close the way to regulate the relations between the Kaunas region and Poland". 158 The Assembly of the League of Nations, in a resolution of 15 September 1921, emphasised that it would not consider a "one-sided solution to the dispute" between Poland and Lithuania, which suggested extending the conflict.

Askenazy was undoubtedly opposed to complete incorporation of Wilno and the Wilno region into the Republic of Poland "without reservations". This position suited the beliefs of Piłsudski and the Minister for Foreign Affairs Sapieha, who had the reputation of a "sworn federalist". ${ }^{159}$ Pointing to the need to obtain "sanctions of the powers", he thought about binding the Wilno region to Poland in a way that would give it a role of "a possible link between Kaunas and Warsaw". He proposed to leave the Wilno Sejm and hold it "in reserve". ${ }^{160}$ He suggested the name of "Wilno land" for the autonomous territory, and the title of the "President of the Wilno Land" for the chairman of the Sejm.

155 Ibid.

156 Ibid. (note of 1 February 1922).

157 Ibid., p. 116 (note of 5 December 1921).

158 Protokoly Komitetu Politycznego Rady Ministrów 1921-1926, ed. M. Jabłonowski, W. Janowski, Warszawa and Pułtusk, 2004, p. 54.

159 Gregory's memorandum related to Sapieha's visit in London on 18 February 1921, DBFP, First Series, vol. XI, London, 1961, p. 723.

160 O Niepodległa i granice, p. 54. 
These concepts corresponded more or less to the views of Piłsudski, who wished to leave "a dose of sovereignty" to Wilno and the Wilno region, as he told Świtalski in January 1922. "If Wilno will say: we agree to autonomy, although we do not want it and we think it unnecessary, as a consequence of adopting such a position a dose of sovereignty must be kept by the Wilno region, that is 1) the Wilno Assembly representation in the Warsaw Sejm, 2) in the autonomy project, a formula so flexible that it allows Wilno to lead negotiations with Kaunas, which will be a must due to the vital connection between the Wilno region and the Kaunas Lithuania, 3) stipulation of the right to vote for representatives of Wilno in matters regarding the legal and national fate of this land". ${ }^{161}$

Of course, these plans of the Chief of State would never come into fruition. In February 1922 the Wilno region will be "integrally incorporated", and the Ruling Sejm will be dissolved. So decided a majority in the Ruling Sejm, which belonged to the National Democracy camp. It is hard not to see this solution of the Wilno issue as an epilogue of Piłsudski's great vision for "reconstructing Eastern Europe", an epilogue negating his intentions. Before incorporating the Wilno territory, Piłsudski voiced his warnings to the Council of Ministers on 10 November 1921. "What the Sejm did was theft. The army took the country with a heroic effort, Sejm did it with a thieving one". ${ }^{162}$ Askenazy unequivocally supported this position. ${ }^{163}$

Elections to the Ruling Sejm were held on 8 January 1922, after the withdrawal of Żeligowski's troops the day before - without the use of force. They yielded results in line with Polish postulates, as the most important thing, the turnout, reached 64.4 per cent. The National Democracy party gained 40 out of 104 mandates of the chamber. The so-called People's Councils, organised by the Borderland Guard, won 29 seats, while democrats and socialists -9 and 3 seats respectively. The Ruling Sejm met on 3 February. On 10 February, it passed an act on the incorporation of the Wilno region into Poland, by a vote of 96 to 6. The Ruling Sejm passed a solemn Act of unification of the Wilno Land and the Republic of Poland, while the Legislative Sejm in Warsaw adopted a resolution on nationality of the Wilno region. ${ }^{164}$ Twenty-four representatives of the Wilno Sejm joined the Sejm of the Republic of Poland in Warsaw.

On 12 January 1922 the Council of the League of Nations heard Hymans' final report from the failed negotiations in Brussels. ${ }^{165}$ The League of Nations

161 Świtalski, Diariusz, p. 126.

162 Ibid., p. 106.

163 Embassy of the Republic of Poland in Paris 53, fol. 69 (Askenazy to Daszyński, Laudański’s portfolio, Kukułka, p. 430).

164 Cf. K.W. Kumaniecki, Odbudowa państwowości polskiej. Najważniejsze dokumenty 1912 - styczeń 1924, Warszawa and Kraków, 1924, pp. 601-602. Important detail in Tommasini, Odrodzenie Polski, p. 224.

165 Sierpowski, Liga Narodów, p. 97. 
considered its mission to be finished. It could be concluded that federational attempts were doomed to fail, they hardly existed, and discussions were limited "merely to clarifying the two points of view". ${ }^{166}$ All that was left was the interesting experience of diplomatic helplessness in the face of a conflict between two nations: on the one hand, a young, exlcusivist Lithuanian nationalism, and on the other - Polish interests, underpinned by geopolitical arguments and referencing history. Tommasini wrote: "the Swiss system, i.e. that of a European country in which political education and the average level of culture are higher, was hardly suitable for a country demoralised by corruption of foreign governments, for the most part mired in illiteracy and ignorance, torn by violent nationalist, political and religious struggles". ${ }^{167}$

The issue of sanctions of the international community for the incorporation of the Wilno region into Poland still remained. On 20 December 1922 Lithuania joined the League of Nations. The country was not a signatory of the Treaty of Versailles. However, Lithuania explicitly recognised the right of the Allied powers to implement article 87 of the Treaty of Versailles in a note from the Minister of Foreign Affairs Ernestas Galvanauskas to the Council of the League on 18 November 1922. ${ }^{168}$ The Council of Ambassadors was now to approve the demarcation of the Polish-Soviet and Polish-Lithuanian borders.

Askenazy had quite pessimistic views on this case. In January 1922 he believed that although "the allies do not want to further interfere in the Wilno issue", "we cannot expect a recognition of the Wilno Sejm and of the annexation of the Wilno region to Poland". ${ }^{169}$ Although the British Foreign Minister Lord Curzon complained about the politics of the government in Kaunas, he warned the Polish envoy to London Władysław Wróblewski that "England will be watching. It will not recognise the incorporation of the Wilno region". ${ }^{170}$

Poland would probably wait a long time for the international community to sanction its eastern borders. Nevertheless, it was possible to take advantage of the exacerbated international situation at the beginning of 1923, in which Askenazy played a part. First, there was a Franco-Belgian intervention in the Ruhr in January that year, later a Lithuanian action in Klaipeda, subdued by Lithuania. ${ }^{171}$ In the face of these conditions, threatening to further destabilise the system of power in Eastern Europe, on 15 March 1923 The Council of Ambassadors approved the eastern borders of the Polish state - thus realising the provisions of article 87 of the Treaty of Versailles. It also recognised the Polish-Lithuanian border as established and de facto valid. "[...] since 1923 Poland had all its borders recognised

166 Ibid., p. 92.

167 Tommasini, Odrodzenie Polski, pp. 220-221.

168 Wielhorski, Polska a Litwa, p. 345.

169 Świtalski, Diariusz, p. 127.

170 Ibid., p. 128 (note of 10 February 1922).

171 Łossowski, Kłajpeda kontra Memel, pp. 37-53. 
by the West", although it did not mean that "they were considered inviolable" in the West, as Henryk Batowski aptly put it. ${ }^{172}$ Although this decision involved the position of the British government, the British Foreign Office from time to time remembered that there was no particular "ethnographic justification" for the territorial regulation created by the Treaty of Riga, and that it was approximately marked out by the range of the Polish offensive in the East in the war with Soviet Russia. ${ }^{173}$ However, what proved most problematic was the German-Polish border, with the "Polish corridor" as an anomaly.

Normalising Polish-Lithuanian relations seemed impossible. Polish concerns that Lithuania may retaliate against Poland were not fading away. This caused demands for Lithuania to reduce its army from sixty thousand soldiers to fifteen thousand. ${ }^{174}$

In March 1922, the young diplomat Marian Szumlakowski wrote to Minister Skirmunt in his programme deliberations about Polish politics regarding Lithuania that in theory Poland was left with the option to bring about the federation solution, either peacefully or by the use of force. "The Lithuanian problem is currently unsolvable for Poland", as persuading Lithuania to voluntarily draw nearer to Poland is impossible, and the use of violence out of the question, which "is an axiom that requires no justification". It is therefore possible only to seek "means to attend to secondary matters". ${ }^{175}$ Also the Lithuanian position did not engender any chances to overcome the conflict. And so in an exposé on 25 February 1927, the Prime Minister Voldemaras defined two immutable rules of Lithuanian politics: "(1) Lithuania must be independent and with its capital in Wilno, and (2) Lithuania must not enter any particularly close relations with any of the great neighbouring countries". ${ }^{176}$ Foreign relations of Lithuania followed this doctrine.

An opportunity to regulate Polish-Lithuanian relations would appear only in 1938, when the Polish government would resort to an ultimatum, using a border incident.

${ }^{172}$ H. Batowski, Zachód wobec granic Polski 1920-1940. Niektóre fakty mniej znane, Łódź, 1995, p. 12.

173 Minutes of a Foreign Office employee Baxter from 11 October 1934, TNA, Foreign Office 371, 17794, C. $6918 / 5968 / 55$.

174 Journal du général Edmond Buat 1914-1923, ed. F. Guelton, Paris, 2015, p. 1261. Note from the Chief of Staff of the French Army of 22 October 1922. From a conversation with Askenazy, erroneously perceived as chargé d'affaires of the embassy in Paris. He also lodged a protest against the sending of French officers-instructors to Lithuania.

175 Łossowski, Stosunki polsko-litewskie, p. 26. Document - see AAN, Embassy in London, cat. no. 347.

176 Cited after Źródła do historii powszechnej okresu międzywojennego, vol. 2: 1927-1934, ed. S. Sierpowski, Poznań, 1992, p. 17. 


\section{III}

\section{The issues of Upper Silesia and Eastern Galicia}

There is no need to stress how significant was the question of Upper Silesia to the reborn Poland. It so happened that the delegate of the Republic of Poland to the League of Nations played a vital role in this issue.

Askenazy, as the second delegate to the League of Nations, dealt with the matters of Upper Silesia. He received support from the professional diplomat Kazimierz Olszowski, head of the Treaty Department in the Foreign Ministry, an expert on international law and treaties. ${ }^{177}$ Undoubtedly, Askenazy was assigned Olszowski as a lawyer on purpose, as the latter was primarily a specialist on Germany and had the reputation of one of the best Polish diplomats.

Askenazy was deeply convinced of Upper Silesia's importance for Poland. In the press article $O$ Ślask, o byt he presented Poland's arguments in the dispute with Germany concerning this territory with remarkable clarity. He posed a strict iunctim between the survival of the reborn state and its worthy place in the family of European nations, and possession of this territory. "Poland cannot live without Silesia. The old, agricultural Republic of Poland could do so, in the old European system. The young, industrial Poland, in the modern world team - cannot. Without Silesia it will not survive, it will not cope with its rebirth, urged to take on huge political and economic tasks. It will not get by, will not manage its self-maintenance, squeezed between two political and economic giants: German and Russian". ${ }^{178}$ The article was also an emergency call addressed to the Polish public. ${ }^{179}$

Let us recall here that on 20 March 1921 a plebiscite was held in Upper Silesia. It gave Germans a little over 59 per cent, with 40.4 per cent of votes for Poland. 479,000 voted for Poland, 707,000 - for Germany. Everyone born after the year 1910 on the plebiscite territory was entitled to vote, regardless of the place of residence at the time of the plebiscite. A third of the votes for Germany came from emigrants brought back from the Reich $(180,000) .{ }^{180}$ This created the threat that the Polish state would receive only two agricultural districts, without the key industrial territory. On 2 May the Third Silesian Uprising broke out.

The question of the affiliation of the contested territory came into the sphere of interests of the Conference of Ambassadors as soon as on 7 May 1921.

177 Jackowski, W walce o polskość, p. 279; K. Skirmunt, Moje wspomnienia 1866-1945, eds. E. Orlof, A. Pasternak, Rzeszów, 1997, p. 116.

178 Kurier Warszawski, no. 27, 27 January 1919 (cited from: Askenazy, Szkice i portrety, p. 183).

179 Noticed by M. Kukiel, Generał Sikorski. Żołnierz i mąż stanu Polski Walczaccej, London, 1970, p. 57.

180 The right of emigrants to vote was requested by Poland, but Germany effectively organised the vote of this national group. Cf. P. Hauser, Powrót na mapę. Walka o granice państwa polskiego po I wojnie światowej, Poznań, 2010, p. 21. 
The point of view presented by Poland was the aspiration to divide the post-plebiscite territory, as far as possible, in accordance with the ethnographic realities. The struggle to carry out through this concept was made more difficult as the British government stood for economic unity of Upper Silesia, in order to avoid the weakening of Germany's ability to pay war compensations. "Extract compensation from Germany" was the British government's priority demand. France, however, was more interested in undermining the defeated enemy's ability to become armed again and its "retaliatory force". ${ }^{181}$ As a result, the French government supported Poland, and the British government - Germany. In a speech on 15 May 1921, the British Prime Minister strongly condemned the Silesian uprising as a revolt against the Allied forces.

Italy was initially in a position clearly reflecting to the British. However, when Francesco Nitti's government collapsed and was replaced by Ivanoe Bonomi's government, while Carlo Sforza was appointed as the Minister of Foreign Affairs, Italian politics evolved somewhat in a more pro-French direction. Tommasini, the envoy to Poland, might have played a role in this. Although Bonomi's government quickly collapsed, the new foreign minister, Marquis della Torretta upheld Sforza's position. ${ }^{182}$

Italy put forward a compromise project - in two versions. These were the so-called Sforza lines. Their guiding idea was to adjust the dividing lines in the contested territory to ethnic relations, reflected in the results of the vote. The first project was much more beneficial to Poland than the second one. Both, however, left a key industrial area on the Polish side, except the second project returned the Königshütte (Królewska Huta) in Chorzów to Germany. ${ }^{183}$

In the face of the great difficulty posed by the question of Upper Silesia's future, the Conference of Ambassadors abstained from a decision on the matter. On 12 August the Supreme Council of the Allied Powers referred the Upper Silesia issue to the Council of the League of Nations. This was "highly unusual", according to a contemporary British historian, as after the formally dissolved, on 21 January 1920, Peace Conference, "outstanding" territorial affairs were to be regulated by the above mentioned Conference of Ambassadors. ${ }^{184}$ However, in this case it was done due to the fact that the differences of opinion between the heads of the French and British governments (Briand and Lloyd George) were so essential that the modus vivendi was deemed impossible.

18 August 1921 was the date of the Memorandum on the Procedure proposed by M. Bourgeois for the Meeting of the Council to deal with the question of Upper Silesia. The document presumed that the Spanish diplomat Quinones de Leon would be the rapporter, which meant that he would appoint external experts needed

181 A. Wysocki, Tajemnice dyplomatycznego sejfu, Warszawa, 1974, p. 41.

182 T. Piszczkowski, Plebiscyt i Powstania na Górnym Śląsku, London, 1972, p. 29.

183 W. Dąbrowski, Górny Śląsk w walce o zjednoczenie z Polską (Źródła i dokumenty z lat 19181922), Katowice, 1923, pp. 99-100.

184 A. Sharp, David Lloyd George. Great Britain, London, 2008, p. 130. 
to carry out the commission's work on an ad hoc basis. However, these experts were to come from among the employees of the General Secretariat who already comprised the technical staff of the League. Professor Bourgeois proposed that the sessions of this body be presided over by Viscount Ishi, i.e. a non-European diplomat, which guaranteed his disengagement in the territorial issues of Poland. ${ }^{185}$

The proposed transfer of Upper Silesia issue to Geneva was accepted by the Polish government not only without protest, but with optimism. Askenazy confirmed this position in a letter to the Japanese representative to the Council of the League, Ishii, on 29 August 1921. He stipulated that he would not make use of paragraph 5 in article 4 of the League's Pact, guided by the spirit of "total confidence in the Council of the League". ${ }^{186}$ In a letter of 31 August, Ishii thanked him for this trust of the Polish government, and communicated its content to the Council. ${ }^{187}$

The Secretary General Drummond informed delegates to the League - Professor Bourgeois, Quinones de Leon, Hymans, da Cunha, and Marquis Imperiali (the Italian representative to Geneva) that he had called the first meeting regarding Upper Silesia for 29 August. ${ }^{188}$

On 1 September 1921 the Council of the League of Nations called a four-member ad hoc commission, also known as the Expert Committee, in order to prepare a working draft of the project of decisions on Upper Silesia. It comprised Hymans from Belgium, a representative of Brazil, Ambassador ad personam Gustao Da Cunha, the Chinese delegate Wellington Koo, and the Spanish diplomat José Quinones de Leon. It also used the services of two other experts - a Czech industrialist and a Swiss railway expert.

Work of the ad hoc committee lasted a month; its liaison with the Council was the French diplomat Paul Mantoux, the then Director of the Political Section at the General Secretariat of the League of Nations. Nationals of the countries involved in the German-Polish dispute were deliberately not selected to the Expert Committee, as they "did not participate in the existing meetings of the powers of this matter". The works of the Committee were chaired by Hymans, and they were surrounded by discretion. ${ }^{189}$ The consultations were not even recorded, which deprives historians of a capital, irreplaceable source.

One of Askenazy's major concerns at that stage of the decision-making process on Upper Silesia was the behind-the-scenes influence of German diplomacy on the prepared decision. Anxiety was triggered by publications in Deutsche Zeitung with leaks on the pending decisions. ${ }^{190}$ It seemed that Germany was remaining

185 SG-SP, La Haute-Silésie, cat. no. 632/11A/14960.

186 SG-SP, cat. no. 630/11A/14705.

187 Ibid.

188 SG-SP, La Haute-Silésie, cat. no. 632/11A/14960.

189 F.P. Walters, A History of the League of Nations, Oxford University Press, 1965, p. 153.

190 An article in Neue Zuricher Zeitung was published on 13 September 1921, entitled "Die Arbeit der Vierer-Kommission des Volkerbundes". 
au courant with the secret Geneva debates. Askenazy drew attention to this with a note to Ishii on 19 September 1921. ${ }^{191}$

During the fight for the Upper Silesia issue at the League of Nations Askenazy undoubtedly gave Poland significant services. He had informal contacts with the Brazilian diplomat, Da Cunha. ${ }^{192}$ According to the diplomat Stanisław Schimitzek, they were allegedly friends. ${ }^{193}$ Recollections of Tadeusz Gustaw Jackowski are a bit different, as he points out that Ambassador Da Cuhna took a "shaky position", both in the Danzig issue and the question of Silesia. ${ }^{194}$ According to Polish reports, Ambassador Da Cunha relayed confidential messages to Askenazy about the work of the Expert Committee. This was of major importance to Polish diplomacy. "Thanks to the Brazilian, Askenazy, and consequently Minister Skirmunt in Warsaw, were confidentially informed about the proceedings of the Geneva Committee", recalled Schimitzek. ${ }^{195}$ "One day, Da Cunha told Askenazy that an opinion is being prepared, according to which the border would be roughly as it was later was fixed, however with Lubliniec on the German side. Askenazy telegrammed the message to Warsaw, from where he was informed that the Polish government would accept the proposed border, provided that Lubliniec and Bytom would be annexed by Poland. In the event of not meeting these minimum amendments, they feared that the embittered Polish population of Upper Silesia would pick up weapons once more, which the government in Warsaw would not be able to stop, and even less to oppose. Askenazy went immediately to his friend, who asked him to write down the names of the disputed cities, and vowed on the honour of a Brazilian gentleman that he would put forward Askenazy's request as his own, and in the event of its rejection would veto the Committee's opinion, for which unanimity was required" ${ }^{196}$ In the end, the Expert Committee presented the Council with a proposal which partially met the latter request. Lubliniec was given to Poland, however Bytom was not. "A question mark remains on the value of the "Brazilian gentleman's word' given to Askenazy" ${ }^{197}$ Mantoux later related to Polish diplomats that the second of the cities could not be found on the map available to the ad hoc Committee. Perhaps, following Schimitzek's account, Askenazy "wrote down for da Cunha, in a hectic rush, most likely the Polish place names, while the maps which the League of Nations was using were German". ${ }^{198}$ Bytom was not found.

\footnotetext{
191 SG-SP, La Haute-Silésie, 632/11A/16018.

192 Sierpowski, Liga Narodów, p. 133.

193 S. Schimitzek, Drogi i bezdroża minionej epoki. Wspomnienia z lat pracy w MSZ 1920-1939, Warszawa, 1976, p. 101.

194 Jackowski, W walce o polskość, p. 252.

195 Schimitzek, Drogi i bezdroża, p. 101.

196 Schimitzek, Drogi i bezdroża, pp. 101-102.

197 Ibid., p. 102.

198 Ibid., pp. 102-103.
} 
Without going into well-known details, let us recall that on 12 October 1921 the Council of the League of Nations passed the division of Upper Silesia. Poland received more than 3,200 square kilometres and 29 per cent of the population. This part included the key economic area of Upper Silesia. Although the area was smaller than it would seem from real ethnic relations, the decision cannot be considered anything but crucially positive for Poland, although the industrial sector remained in German hands.

The Council of the League did not alter the project submitted by the ad hoc committee regarding the Polish-German border. It accepted it practically ne varietur. It ultimately proved possible, as a French delegate Leon Bourgeois reached an agreement with Lord Balfour, whose views on the Upper Silesian issue differed from that of Lloyd George's. ${ }^{199}$ On 20 October 1921, The Conference of Ambassadors, meeting in Paris, also adopted ne varietur the resolution of the Council of the League of Nations. The proceedings took place in the presence of Ambassadors to Paris: British Hardinge, Italian Bonino, Japanese Ishii, and a representative of France, Jules Cambon. ${ }^{200}$ The meeting was presided over by Aristide Briand, the French Minister of Foreign Affairs, and at the same time the Prime Minister of the government, who announced the passed resolution in a separate letter to the Ambassador of the German Reich and to the envoy of the Republic of Poland to Paris. ${ }^{201}$

In a letter dated 24 October 1921, the envoy to Paris, Maurycy Klemens Zamoyski, informed the President of the Supreme Council, Briand, that Poland wholly accepted the resolution of the Council of the League of Nations on the division of the post-plebiscite territory of Upper Silesia. Two days later, Ishii passed on the démarche to Drummond. ${ }^{202}$ Signs of anger and great commotion were reaching Geneva from Germany. German protests were lodged with the General Secretariat of the League against the resolution of its Council. ${ }^{203}$ Granting Poland a substantial part of Upper Silesia was a great and unexpected defeat of German diplomacy.

On 27 October 1921 the envoy Zamoyski sent Briand information about the appointment of Kazimierz Olszowski as the head of the Polish delegation for the negotiations of the Upper Silesian convention. ${ }^{204}$ Polish diplomacy was facing

199 More in T. Piszczkowski, Anglia a Polska 1914-1939. W świetle dokumentów brytyjskich, London, 1975, p. 196.

200 SG-SP, La Haute-Silésie, cat. no. 632/11A/16923.

201 Text of the letter - see Kumaniecki, Odbudowa państwowości polskiej, p. 576. Following Millerand's resignation on 21 September 1920, Georges Leygues served as the Prime Minister from 24 September 1920 to 16 January 1921; the post was then held by Briand from 16 January 1921 until 14 January 1922, jointly with the office of the Foreign Minister, and from 15 January 1922 to 9 June 1924 the leader of the government was Raymond Poincaré.

202 SG-SP, La Haute-Silésie, cat. no. 632/11A/17010.

203 Id., cat. no. 16756, 16524, 16520, 16492, 60843, 50138, 43137.

204 Id., cat. no. 632/11A/14960. Germans announced in Geneva that their representatives would be: the former Minister of the Reich Schiffer, and State Secretary Lewald. 
long and difficult talks for the establishment of a special regime in Upper Silesia, split into two parts.

As we learn from the documents of the League of Nations, on 7 November 1921 Askenazy had a conversation with its Secretary General, Drummond. He had come to speak to him about the further consequences of the issue of Upper Silesia, successfully resolved for Poland. ${ }^{205}$ Drummond suggested Polish-German talks about settling the question of dividing the post-plebiscite territory on site - ideally in Upper Silesia, where access to information, necessary for the negotiation process, would be easier. It would also proceed faster. The Secretary General advised to at most start the talks in Geneva and then move them to Upper Silesia. Askenazy thought this the best plan, but loudly wondered which place to choose - Katowice, Bytom, or perhaps Opole. He also raised the issue that the Polish government had rejected the German offer of direct negotiations and relied on the League of Nations, as Poland had "full trust" for it. He insisted very strongly not to delay sending a Swiss mediator to Poland. It must be someone with authority, and "not just a factory expert", Askenazy said. Drummond shared this reasoning completely. Let us add that on 20 October 1921 the Conference of Ambassadors had already decided to ask the Council of the League of Nations to appoint a person to chair GermanPolish talks, and appoint chairmen of the Mixed Commission and the Arbitral Tribunal for Upper Silesia - about which Briand immediately notified Ishii. ${ }^{206}$

The mediator was to be Gustave Ador (former president of the Swiss Confederation and head of the International Red Cross). His candidacy was strongly contested by Germany and collapsed. ${ }^{207}$ It was replaced by a new personal proposal - in the person of another Swiss politician Félix Calonder, President of the Swiss Federal Council. ${ }^{208}$ In the years $1922-1937$ he would be the chairman of the Upper Silesian Mixed Commission.

Protecting the economic unity of Silesia after demarcating the border was supposed to be ensured by the German-Polish convention signed in Geneva on 15 May 1922, henceforth referred to as the Geneva Convention, which would apply until 1937, i.e. for fifteen years. This extensive document consisted of as many as 606 articles. ${ }^{209}$ It regulated the details of various areas of life. The guarantee system of the German minority rights in Upper Silesia was most definitely an

205 Archives de la Société des Nations (Geneva), Fonds Prives, Drummond Papers 1919-1930, Box 81/5.

206 SG-SP, La Haute-Silésie, cat. no. 632/11A/16923.

207 It has been written about by Paul Stauffer (Swiss historian and diplomat): Polacy, Żydzi, Szwajcarzy, Warszawa, 2008, pp. 18-19. Auswärtiges Amt in Berlin saw Ador as an anti-German politician. The allegation of his bias, made before the nomination, proved to be effective.

208 On Calonder's mission see P. Stauffer, “Mąż stanu Europy przyszłości’? Félix Calonder i jego działalność w niemiecko-polsko-żydowkiej strefie napięcia na Górnym Śląsku (1921-1937)”, in: Polacy, Żydzi, Szwajcarzy, pp. 13-92.

209 In detail in A. Szczepański, Górny Śląsk w świetle Konwencji Genewskiej, Warszawa, 1929. 
unprecedented international legal experiment, in terms of the existing political relations in Europe. ${ }^{210}$ For this reason it attracts the attention of historians of interwar diplomacy.

The convention was ratified in June 1922, and on 17-22 July Polish armed forces entered the area of Upper Silesia granted to Poland. It was the last act of annexing a significant territory by the Republic of Poland. The process of constructing the country was complete. However, Polish diplomacy was facing a tough task of fighting the German argument, persistently claiming that Upper Silesia was indispensable for Germany in rebuilding the economic life in its own country. ${ }^{211}$

Factors in the country unfriendly towards Askenazy tried to diminish his role in the issue of Upper Silesia. This was expressed by an anecdote, which we find in Paderewski's political papers - in one of the letters written to him by Sylwin Strakacz on 5 December 1921. Allegedly, Bourgeois, Balfour and Drummond (Secretary General of the League) were talking at a meeting in Geneva. Bourgeois was to say: "Do you know, Sirs, that the Polish envoy Mr. Askenazy has arrived in Geneva today?", to which Balfour replied "Has he? I didn't know". Drummond joined in, "I now understand why yesterday's resolution is so successful for Poland". ${ }^{212}$ This unkind story was to show that as the second delegate of the Republic of Poland, Askenazy, ironically called "our talented representative and a great diplomat", did virtually nothing, and that issues of Silesia were decided by the actions of France, whose interests ordered it to favour Poland.

On 3 May 1922, the Chapter of Polonia Restituta awarded this order to several prominent diplomats for their contributions to the division of Upper Silesia. Askenazy, Zamoyski and Aleksander Skrzyński received the Commander's Cross with Star; Kajetan Morawski (Director of the Political Department) and Stefan Przeździecki, the creator and head of the Diplomatic Protocol of the Ministry of Foreign Affairs, were awarded the Commander's Cross. The decorations were presented by the Chief of State.

The year 1922, above all its second half, was the time of Askenazy's efforts to carry out the issue of autonomy for the former Eastern Galicia. The efforts did not end in a positive result, but he could not have achieved more.

We should remember that the first days of Poland's independence coincided with the outbreak of the Polish-Ukrainian conflict over Lviv and Eastern Galicia in early November 1918. Poland managed to end this war victorious in June 1919.

${ }^{210}$ Georges Kaeckenbeeck called Upper Silesia's status “an international experiment”, The International Experiment of Upper Silesia, London and Oxford, 1942.

211 Bibl. Pol., cat. no. acc. 4347, Memorandum from 4 January 1921, prepared by the Polish Congress Delegation - sent to London for the Delegation; "Note sur les repercussions économiques du transfert eventuel de la Haute-Silesie à la Pologne", written on 25 October 1920.

212 Strakacz to Paderewski, letter from 5 December 1921. He reported that the fact that Askenazy was recalled to Warsaw in the days preceding the crucial decision to split Upper Silesia was used. APP, ed. H. Janowska and C. Madajczyk, Wrocław, 1974, vol. 21, p. 35. 
Internationally, the Ukrainians protested against "the barbarian occupation of Eastern Galicia by Polish troops". The League of Nations, acting as a mediator, set up a special committee for the Polish-Ukrainian conflict headed by General Louis Botha, representing South Africa (as a British dominion) in Geneva. However, the committee's conclusions regarding a truce were rejected by the Polish government, as this would require recognising the equality of the sides. This would lead the Ukrainian People's Republic to receive the status of a subject in international relations. ${ }^{213}$ It should be recalled that, for the same reason, the Polish government refused to sign the treaty "about certain borders in Eastern Europe", submitted by the Allied powers on 10 August 1920 in Sèvres. The Treaty laid down the political concept of "Eastern Galicia".

During the session of the Botha committee on 27 April 1919, Polish delegates to the Peace Conference, Paderewski and Dmowski, demanded that Poland be granted the right to control Eastern Galicia in its entirety, as well as parts of Volhynia and Rivne. In May, the Committee presented the terms of the ceasefire, but as it left the oilfields on the Ukrainian side, they were rejected by the Polish side in their entirety. The Botha Committee acknowledged the its mission was exhausted. ${ }^{214}$ In May, the Polish army intensified its decisive offensive against the Ukrainians. In the face of these facts, on 25 June 1919 the Allied Supreme Council authorised Poland to occupy Eastern Galicia. In September that year Poland was entrusted with this territory as a mandate for twenty-five years. ${ }^{215}$ At the end of this period, a plebiscite was to be held under the auspices of the League of Nations.

This solution satisfied neither Poland nor Ukraine. To the Polish opinion it was, in fact, offensive; for Ukrainian factors it was evidence of bias towards the stronger side. At the same time, the political concept of "Eastern Galicia" was created - until then unknown - used expressis verbis in the "Treaty of certain borders in Eastern Europe", signed in Sèvres on 10 August 1920. It was not signed by Poland, precisely because of the fact that the text of the treaty used the concept of "Eastern Galicia". ${ }^{216}$ For this reason, the treaty did not enter into force.

The Supreme Council considered various options. The first idea was to include Lviv and the oilfields in Borysław to Poland, and with the rest to create an autonomous mandate country of the League of Nations. The second option

${ }^{213}$ For a more detailed discussion of this issue see Z. Zaks, "Sprawa Galicji Wschodniej w Lidze Narodów (1920-1922)”, Najnowsze Dzieje Polski. Materiały i Studia z Okresu 1914-1939, 12 (1967), pp. 127-153. Cf. also A. Leinwand, "Walka dyplomatyczna Polski o Galicję Wschodnią (1918-1923)", Studia z Dziejów Rosji i Europy Wschodniej, 46 (2011), pp. 85-98.

214 J. Pisuliński, Nie tylko Petlura. Kwestia ukraińska w polskiej polityce zagranicznej w latach 1918-1923, Wrocław, 2004, pp. 130-132. Cf. also Z. Zaks, "Walka dyplomatyczna o naftę wschodniogalicyjską (1918-1923)”, Z Dziejów Stosunków Polsko-Radzieckich. Studia i Materiały, 4 (1969), pp. 37-60.

215 Batowski, Między dwiema wojnami, p. 53.

216 Ibid., p. 54. 
was to grant Poland the administration (occupation rights) of the areas east of the so-called Curzon Line. ${ }^{217}$

We should keep in mind that in Spa there were attempts to impose a ceasefire line on Poland in the war with Soviets, which coincided with the Curzon Line, as outlined and passed by the Supreme Council on 8 December 1919, but by moving this line further south, thus dividing Eastern Galicia east of Przemyśl until the Carpathians, but leaving things unclear regarding Chełm Land. ${ }^{218}$ Such a solution was proposed, in a famous note to the Soviet Government, by the British Foreign Minister Lord Curzon on 11 July 1920. The position of France did not differ fundamentally, although French diplomacy took efforts not to treat the Curzon Line as final. ${ }^{219}$ French politics was under Russian influences. Askenazy called the Secretary-General of the Quai d'Orsay, Philippe Bethelot, "our former enemy and Izvolsky's creature". ${ }^{220}$ We can also add that at the beginning of 1920, Foreign Minister Stanisław Patek, speaking to Clemenceau, heard a warning: "Just do not lead an invasive war, or the Allies will lose confidence in you...".221

Naturally, the struggle of Polish diplomacy against the Curzon Line was a top priority. "Develop a memorandum proving the nonsense of the Curzon Line", Piłsudski told Władysław Baranowski. ${ }^{222}$

In October 1920 Askenazy travelled to London. He was to make contact with British politicians (Eric Drummond, Herbert Fisher, William Tyrell, James Gregory, Lord Hardinge) - regarding the future of Eastern Galicia. ${ }^{223}$ The mission failed. On 23 February 1921, in a new resolution on Eastern Galicia, the Council of Ambassadors, declared that Poland was an occupant, and that the Allied Powers were responsible for sovereignty on this territory. ${ }^{224}$

The efforts of the Polish diplomacy to achieve a definitive explanation of the status of Eastern Galicia intensified in 1922. New opportunities opened up thanks to the resolution of Charles J. Doherty, passed by the General Assembly on 27 September 1921, and stating that Poland should grant self-government rights to territories of the former Eastern Galicia. The Canadian diplomat put forward a proposal for the autonomy of Eastern Galicia. Askenazy managed to stop it from

\footnotetext{
217 T. Piszczkowski, Odbudowanie Polski 1914-1921, pp. 247-248. This monograph, based on careful research in the archives of the Foreign Office, introduces a lot of insights into the British policy regarding Polish affairs.

218 Text in: Kumaniecki, Odbudowa państwowości polskiej, pp. 291-292. Cf. also Batowski, Między dwiema wojnami, p. 60; id., Zachód wobec granic Polski, p. 11.

219 It was noticed by the ambassador J. Laroche, "La Question de Teschen devant la Conference de la Paix", Revue d'Histoire Diplomatique, vol. 62 (1948), pp. 8-27.

${ }^{220}$ Cited from Kukułka, Francja, p. 241 (Teki Laudańskiego, CAW, vol. 440, 12/7).

${ }^{221}$ Patek to Piłsudski, 5 January 1920, JPIA, GACC.

222 Baranowski, Rozmowy z Piłsudskim 1916-1931, p. 135.

${ }^{223}$ Nowak-Kiełbikowa, Polska - Wielka Brytania, p. 278.

224 Ibid., pp. 280-281.
} 
being passed, and instead it was referred to the Conference of Ambassadors. ${ }^{225}$ At the same time he proved to be an ardent spokesman for the idea of granting autonomy to the south-eastern voivodships of the Republic of Poland, in order to get the favour of the Allied powers. ${ }^{226}$

The original bill was developed by Professor Michał Bobrzyński - a historian, former Governor of Galicia, a politician deeply involved in the idea of PolishUkrainian reconciliation - at the personal request of the Prime Minister Antoni Ponikowski. During the government of Julian Nowak (June-December 1922) works intensified. The project was repeatedly debated and corrected, ${ }^{227}$ we will not describe these debates in detail here.

On 7 August 1922 at the meeting of the Political Committee of the Council of Ministers, Askenazy presented the situation of the Eastern Galician issue on the international arena. He requested that a draft be prepared for the statute of this region's autonomy, for the purpose of delivering it to the Supreme Council. ${ }^{228}$ The prepared text was to be submitted by Foreign Minister Gabriel Narutowicz to the Council of Ambassadors in Paris. ${ }^{229}$ The environment of Ukrainian political emigration considered this offer unacceptable. ${ }^{230}$

On 26 September 1922, Sejm passed a law granting autonomy to three south-eastern voivodships of the Republic of Poland (Lviv, Tarnopol and Stanisławów), according to the submission of Julian Nowak's government. It made it possible to i.a. introduce equal rights of the Ukrainian language on these territories. The act, however, would never be implemented. The appropriate ministers never issued the necessary executive regulations. ${ }^{231}$ A day later (on 27 September) Askenazy presented a declaration of autonomy for the territories of the former Eastern Galicia. ${ }^{232}$

According to the recollections of Prime Minister Nowak, Askenazy and Narutowicz were against holding a general election as early as in November 1922, and for postponing it in order to first settle the issue of Eastern Galicia's autonomy. ${ }^{233}$ It did not happen so. The election was held. The executive regulations for the act on the autonomy of eastern voivodships were never issued; it became a dead letter.

225 M. Bobrzyński, Wskrzeszenie państwa polskiego, vol. 2: 1918-1923, Kraków, 1925, p. 259.

${ }^{226}$ Nowak-Kiełbikowa, Konstanty Skirmunt, pp. 120-121.

227 Cf. detailed analysis in: Pisuliński, Nie tylko Petlura, pp. 358 and f. Cf. Also Bobrzyński's account of these works: Wskrzeszenie państwa polskiego, vol. 2, p. $263 \mathrm{ff}$.

228 Protokoly Komitetu Politycznego Rady Ministrów 1921-1926, p. 88.

${ }^{229}$ Cienciała, Komarnicki, From Versailles to Locarno, p. 200. Narutowicz replaced Skirmunt in the short-lived cabinet of Artur Śliwiński, and then joined the government of Julian Nowak.

230 The Prime Minister-in-exile of the Ukrainian People's Republic Yevhen Petrushevych considered it "illegal”. Cf. A. Zięba: Lobbing dla Ukrainy w Europie międzywojennej. Ukraińskie Biuro Prasowe w Londynie oraz jego konkurenci polityczni (do roku 1932), Kraków, 2010, p. 102.

231 Nowak's cabinet was a typical "transitional government" and functioned until the parliamentary elections in December 1922.

232 Nowak-Kiełbikowa, Polska - Wielka Brytania, p. 353.

233 J. Nowak, Wspomnienia z ławy rządowej, Kraków, 1938, p. 50. 
Another major issue was the subject of Szymon Askenazy's Geneva mission. It was the Jewish issues. We should remember that for Polish diplomacy at the League of Nations the complex Polish-Jewish relations, exacerbated after the Soviet-Polish war, were becoming increasingly important.

Already as a delegate of the Foreign Propaganda Office, Askenazy wrote to Daszyński on 20 September 1920 about "the fatal echoes of anti-Jewish repressions after repelling the Bolsheviks in the recovered cities". It is worth mentioning that the Allied mission of General Barthelémy to Poland at the beginning of 1919 received a letter about a Jewish pogrom in Lviv, presented by the Jewish Rescue Committee. ${ }^{234}$ The international overtones of these and other activities had their significance. "Information on the matter is brought here by numerous eyewitnesses, Jews, and partly Americans. This provokes a new resurgence of the somewhat calmer anti-Polish sentiments in the Jewish circles here, and even in the Christian ones they are close to. The business of the greater or lesser extent of the guilt of certain Jewish groups as leaders of the Bolshevik invasion was here essentially repealed as a secondary factor, as far as it is not about self-defence but about repressions after the achieved victory". ${ }^{235}$ In a report for the Ministry of Foreign Affairs of 6 December 1920, Paderewski devoted his attention to this issue. "The Jewish issue", he wrote, "in recent times has again become greatly relevant for us. Jewish activists are arriving in Geneva from all directions (Wolf, Sokolov, Zangwill, Sylvain Lévi - the Chairman of the Alliance Israélite). There is great excitement among them. I have been warned that a great attack of Jews on Poland is being planned, and today they have apparently won over several members of the Assembly [of the League of Nations], and Lord Robert Cecil was supposed to take a stand against laws we are allegedly violating". ${ }^{236}$

Askenazy established extensive contacts with Jewish communities. Polish documents mention e.g. his relationship with Lucien Wolf, president of the Alliance Israélite Universelle, through which the Polish side sought to relax the relations with international Jewish communities and to counter "anti-Polish factors" ${ }^{237}$ As indicated by a letter from Lucien Wolff to Rabbi Montefiore, found in Foreign Office papers, the president of the Alliance Israélite Universelle perceived Askenazy as an instrument of Polish diplomacy. He wrote: "I assume that Askenazy is being employed to soothe us, and I do not think it advisable to fall into his arms and accept all his assurances as gospel". 238

234 The Chairman of the Committee was Tobiasz Aszkenaze. Cf. M. Tyrowicz, “Aszkenaze Stefan Tobiasz (1863-1920), Polski Słownik Biograficzny, vol. 1 (1935), p. 174.

235 Raporty i informacje Biura Propagandy Zagranicznej, p. 80.

236 APP, vol. 2, p. 597.

237 Ibid., pp. 588-589 (protocol from a meeting of the Republic of Poland Delegation from 1 December 1920).

238 TNA, Foreign Office 371, 5398, N.435/96/55. Wolff talked to Askenazy in London on 11 October 1920 (letter with the same date). 
In all matters relating to the Polish-Jewish relations, Askenazy maintained a position dictated by the understanding of Polish state interests. It is significant that during Henry Morgenthau's mission in Poland (July-September 1919), aiming to examine the situation of the Jewish population in the reborn Poland, Askenazy expressed an opinion which showed beyond any doubt how clearly he identified with the interests of Poland. In a conversation with Morgenthau on 15 July 1919, he said that Jews should trust the Poles' "intelligence and generosity" as well as "the virtues of the Polish national character". He also spoke against the idea of separate Jewish education system. ${ }^{239}$ He correctly read the use of anti-Semitism accusations by anti-Polish factors, pointing out to Ignacy Daszyński that these accusations are deliberately extended "to the legions and the Polish left". ${ }^{240}$

"I am a Minister of the most Majestic Republic of Poland, but I am also a descendant of Chacham Tzvi!" (a prominent seventeenth-century rabbi in Lviv), he declared during one of the meetings to the representatives of the Alliance Israélite Universelle, according to Gawroński. He also managed to persuade the organisation to abandon the idea of demonstrating against Poland in Geneva. ${ }^{241}$ "He was the strictest, the most ruthless towards his fellow believers. From the numerous Polish Jews settled in Geneva, he demanded firmly not to make his work difficult by lodging or supporting complaints referring to the convention on the protection of minorities. As his insistence, or rather his orders did not bring full results, he closed the doors of the Polish delegation to them once and for all", recalled Kajetan Morawski. ${ }^{242}$

"In his studies and considerations", wrote Jan Gawroński, "Askenazy was a Polish patriot, deeply attached to our homeland, ready to serve it with every effort, every sacrifice. By blood and origin, he was a Jew, he felt a hundred per cent Jewish and was immensely proud of his belonging to this nation, which boasts the longest run of unbroken history and culture. However, he was also a true aristocrat, who believed in the spiritual significance of centuries-old traditions. Odi profanum vulgus et arceo". ${ }^{243}$

Askenazy left a good impression behind him in Geneva, although he was undoubtedly not one of those who spontaneously win people's sympathy. Kajetan Morawski wrote in his diary: "The memory of Askenazy was alive in Geneva when I arrived in 1924 as a Minister-Resident at the League of Nations. In the circles of the Secretariat, he was spoken about with respect, but with a certain retrospective fear. He was remembered for disregarding, when carried away by fighting spirit,

239 P. Różański, Stany Zjednoczone wobec kwestii żydowskiej w Polsce 1918-1921, Gdańsk, 2007, p. 315. (Incidentally, "Polish race" is more likely the Polish national character and not the Polish ethnic group as the author puts it).

240 Report of 19 October 1920, CAW, cat. no. I. 440.12/6-7.

241 J. Gawroński, Dyplomatyczne wagary, Warszawa, 1965, p. 57.

${ }^{242}$ K. Morawski, Tamten brzeg. Wspomnienia i szkice, Paris, 1960, pp. 56-57.

243 Gawroński, Dyplomatyczne wagary, p. 57. 
the new international phraseology and etiquette forming over Lake Léman, for treating the most venerated thinkers of the League Areopagus brusquely and unceremoniously". ${ }^{244}$

"Monsieur Askenazy dans la politique... il ne connaît pas, bien entendu, grand chose... Mais dans l'histoire il est vraiment très fort...", wrote the French political columnist Pierre Bernus about the Polish historian and diplomat. ${ }^{245}$ William Max-Muller, old-school diplomat and delegate to Poland, was also unfavourable: "personally I find A[skenazy] one of the most asphyxiatic bores that I have ever come across, while his oily manner towards those who he considers his superiors combined with his bullying of his inferiors is most unpleasant to me". ${ }^{246}$

Paderewski had a high opinion about the position of Askenazy in the PolishJewish conflict, which is even more remarkable as their personal relations remained bad. In a letter to Sapieha from 31 December 1920 about the grounds for his resignation, he praised the fight against the anti-Polish campaign of Jewish communities. "The already prepared questioning on the Jewish issue [during the First General Assembly of the League - MK] was prevented by Mr. Askenazy's rather earnest participation. At present I do not wish to say any more about Mr. Askenazy". ${ }^{247}$

Particularly unfair, therefore, are the aforementioned Roman Dmowski's remarks about Askenazy in his Polityka polska i odbudowanie państwa, that he "could take another homeland" if "Poland was lost". These opinions distinctly show resentment and hostility. Alongside the anti-Jewish attitude of the author, it was probably also, to some extent, the result of another vision of the reborn Poland and, above all, orientation disputes from the First World War. ${ }^{248}$

244 Morawski, Tamten brzeg, pp. 56-57.

245 Cited from Z. Lubicz-Zaleski, Dziennik nieciagty (1904-1925), ed. M. Willaume, Paris and Łódź, 1998, p. 265 (note of 30 August 1920).

246 A letter by Max-Muller (then still employed in the Foreign Office) from 30 November 1921 to the chargé d'affaires of the United Kingdom in Warsaw, J. Gregory, TNA, Foreign Office 371, 6842, N.13363/13363/55.

247 APP, vol. 2, p. 618.

248 The mutual antipathy between Dmowski and Askenazy had a long history. And so, on 13 September 1901 Dmowski wrote to Zygmunt Miłkowski that he did not "like [Askenazy], contrary to the numerous expressions of admiration", and that his "concept of the Polish raison d'état" was inaccurate (see M. Kułakowski [J. Zieliński], Roman Dmowski w świetle listów i wspomnień, London, 1968, vol. 1, p. 237). In the name of historical accuracy, it should be noted that Askenazy had already fiercely attacked Dmowski during the Great War (it is discussed by A. Micewski, Roman Dmowski, Warszawa, 1971, p. 230). After the war, in Uwagi (1924), Askenazy devoted a lot of space to Dmowski, referring to documents published by the Bolsheviks concerning his contacts with Russian politicians in 1914-1916. They show an image of a pro-Russian orientation of the National Democracy's leader (pp. 436-438, 440, 442-443 and 449. He also described as "a fairy tale" the claim about Dmowski's actions influencing British diplomacy to cause the Declaration of the Russian Interim Government of 30 March 1917 on the independence of Poland (p. 463). Askenazy could also be unjust in his judgements. Jan Lechon recorded his words, probably repeated more broadly, that even if "Paderewski and Dmowski fell to their knees at Versailles before the coalition, it would not be able to give us less than we got from it" 
Zygmunt Lubicz-Zaleski, associated with the National Democracy camp, spoke very negatively about Askenazy. He accused him of "cheap dexterity" and "cloying courtesy". ${ }^{249}$

It is hard not to notice that a certain distrust of Askenazy on the part of diplomats from the National Democracy camp, but also among the people from the Pilsudski spheres, was certainly making his job more difficult. ${ }^{250}$

There is no exaggeration in the saying that Askenazy was fought by National Democracy, socialists, and Zionists. ${ }^{251}$ However, he remained the master for "the best young generation diplomats", in the words of Jan Lechon. ${ }^{252}$

The National Democracy camp briefly took over the Foreign Affairs of the state - for the first time since regaining independence. After overthrowing General Sikorski's cabinet at the end of May 1923, Marian Seyda replaced Aleksander Skrzyński as Foreign Minister. This change essentially "did not alter anything in Polish foreign policy, and in particular it did not do anything about the German issue, [but] was famous for carrying out personnel purges at the Ministry of Foreign Affairs". ${ }^{253}$

Seyda's moves were aimed to remove people involved in the "activist" camp during the First World War from the Ministry, as well as people from among Piłsudski's supporters and leftist groups. ${ }^{254}$ Stanisław Kętrzyński (historian of the Middle Ages and until then Director of the Political Department) left the foreign service. Also Władysław Baranowski and Władyslaw Neuman, one of the most intelligent diplomats of the younger generation, were removed. ${ }^{255}$ Major Józef Beck, military attaché in Paris, left the service. ${ }^{256}$ Others who left included Zygmunt Stefański, Bronisław Bouffał, Kazimiera Iłłakowiczówna, Wincenty Rzymowski,

(J. Lechoń, Dziennik, Warszawa, 1993 [1st ed., London, 1973], vol. 3: 1 stycznia 1953 - 30 maja 1956, p. 207, note of 12 September 1953). Finally, it is worth noting that in many cases - e.g. on the question of the close connection between possession of Upper Silesia and real independence of Poland, Askenazy and Dmowski were almost identical in their views (see the above mentioned article by Askenazy $O$ Śląsk, o byt).

249 Lubicz-Zaleski, Dziennik nieciagty, p. 265 (note of 30 August 1920).

250 "I spoke today about Mr. Askenazy's trip with your Neumann, who asks to let you know in confidence that in his opinion Mr. Askenazy will come to London without any government programme, but at most with his own. Therefore, instead of listening to him you will need to follow the path of inspiring him from the very beginning", wrote Tadeusz Romer (then Secretary of the legation in Paris) to Jan Ciechanowski (chargé d'affaires in London) on 2 October 1920, PISM, Kol. 82/7 (files of Ciechanowski).

${ }^{251}$ H. Barycz, Na przełomie dwóch stuleci. Z dziejów polskiej humanistyki w dobie Młodej Polski, Wrocław, 1977, p. 250.

252 Lechoń, Dziennik, vol. 3, p. 403 (note of 26 June 1954).

253 A. Micewski, Z geografii politycznej II Rzeczypospolitej. Szkice, Warszawa, 1984, p. 122.

${ }^{254}$ W. Jędrzejewicz - statement in the survey conducted by Piotr Wandycz, "MSZ w okresie międzywojennym", Zeszyty Historyczne 38 (1976), p. 128.

255 Łossowski, Dyplomacja, p. 50.

${ }^{256}$ Kornat, Józef Beck, p. 71. 
Henryk Strasburger, Leon Berenson, Aleksander Lutze-Birk. ${ }^{257}$ Baranowski sued by the Ministry of Foreign Affairs before the Supreme Administrative Tribunal; he received a favourable judgment and returned to the Ministry. ${ }^{258}$

In order to pre-empt his dismissal from the position in Geneva, Askenazy resigned in July 1923. As Schimitzek puts it, this was "not exactly a voluntary resignation". ${ }^{259}$ Seyda could not trust Askenazy - this much remains unmistakable. ${ }^{260}$ After Askenazy's resignation, no new delegate of the Republic of Poland was nominated. These obligations were to be taken over and combined with existing duties by the envoy to London, former minister of Foreign Affairs Konstanty Skirmunt, which "in the Senate in Gdańsk was received with relief". ${ }^{261}$

After leaving Geneva, Askenazy did not return to diplomatic service. He was one of the people which Poland did not use to the full. He still took part in the issues of public life in Poland. During the fierce battle for a law on military chiefs in 1924, Askenazy stood clearly by General Sikorski (then Minister of Military Affairs), not Piłsudski. He wanted to contribute to winning over the House majority for the government project. ${ }^{262}$ Askenazy "patrons Sikorski", wrote the then Speaker of the Sejm Maciej Rataj in his "Dziennik" on 23 December 1924. ${ }^{263}$ Askenazy also became closer with the Foreign Minister Skrzyński, who - according to Rataj "declared his willingness to send him to a diplomatic post, e.g. to the Quirinal". ${ }^{264}$ However, this was not to be, and when Skrzyński appointed the Science Council at the Ministry of Foreign Affairs in 1925, Askenazy did not find a place in it, while his great opponent Marceli Handelsman became its chairman.

After the May coup, it seemed that Askenazy would come back to serve in the Foreign Ministry. Rumours about it circulated in the diplomatic spheres. Stanisław Janikowski (Deputy Head of the Eastern Division) spoke in this way in a conversation with the Soviet envoy Voykov. ${ }^{265}$ "I have a feeling that Askenazy will eventually go to London", wrote the diplomat Tytus Komarnicki to Jan Łoś, who was then

257 Dyplomaci II RP w świetle raportów Quai d'Orsay, ed. J. Łaptos, Warszawa, 1993, p. 13.

258 Cited from: P. Wandycz, Aleksander Skrzyński minister spraw zagranicznych II Rzeczypospolitej, Warszawa, 2006, p. 80.

259 Schimitzek, Drogi i bezdroża, p. 83.

${ }^{260}$ In his memoirs he did not pay much attention to him, but noted, somewhat maliciously, that the translation in Uwagi Bündnissverhältnis is a "covenant relationship" rather than a "union relationship" (see M. Seyda, Polska na przełomie dziejów. Fakty i dokumenty. Od zbrojnego wystapienia Stanów Zjednoczonych do końca wojny, Poznań and Warszawa, 1931, p. 71).

261 Stępniak, Polska i Wolne Miasto Gdańsk, p. 82.

${ }^{262}$ He allegedly tried to persuade Stanisław Thugutt, the leader of the Polish People's Party "Wyzwolenie". Cf. M. Rataj, Pamiętniki, ed. J. Dębski, Warszawa, 1965, p. 260.

263 Ibid., p. 265.

264 Ibid., Pamiętniki, p. 293. It would be the position of a Polish envoy at the government of the Kingdom of Italy.

265 Cf. M. Wołos, O Piłsudskim, Dmowskim i zamachu majowym. Dyplomacja sowiecka wobec Polski w okresie kryzysu politycznego 1925-1926, Kraków, 2013, p. 206. 
an envoy in the capital of the United Kingdom. ${ }^{266}$ It did not happen, however. In another letter to Łoś from that time, Komarnicki writes: "I can confidentially inform you that the main resistance against the Professor came from the Marshal". ${ }^{267}$

Perhaps Askenazy may have still been remembered for his statement to Kazimierz Switalski from the summer of 1920, that the Chief of State ought to resign from his position in favour of General Weygand?268

In any event, if we are to trust the accuracy of August Zaleski's account, we can conclude that Askenazy did Piłsudski a great favour in May 1926. On 12 May, he was to advise General Sikorski - who was calling him from Lviv, asking for advice - to stay passive in the fight for Warsaw. This was to allow him to avoid more bloodshed. Askenazy suggested that Sikorski should remain with his troops on the spot, "adding to his conduct the motive of the Russian threat". ${ }^{269}$

Let us summarise in four general observations:

(1) We can say that the art of diplomacy is three overall skills: primo, analysis of the reality surrounding one's own state; secundo, decision making; tertio, negotiation. The three-year Geneva mission provided, above all, an opportunity to play a key role in this first area, and to a lesser extent in the third. The decision sphere was always the domain of state government and the Foreign Ministry headquarters - in this particular case especially Minister Eustachy Sapieha. ${ }^{270}$

(2) Askenazy's Geneva mission lasted from 15 November 1921 until 11 July 1923. ${ }^{271}$ It occurred in the period of real impact of the newly formed League of Nations on the shape of international relations and settling territorial disputes in post-war Europe. This is also the reason why a study devoted to Askenazy - the diplomat must delve deeply into the matter of Polish foreign policy in the years 1920-1923. His successors in the Geneva post faced a different, probably easier, reality, as they did not have to deal with matters of such grave importance as territorial conflicts of the reborn Poland. ${ }^{272}$ Never had there been (after 1922) such

266 State Archive in Lublin, corpus: Łoś Archive from Germany, cat. no. 370 (letters of T. Komarnicki to Jan Stanisław Łoś, 21 June 1926, k. 15). I would like to thank Professor Jan Pisuliński of the University of Rzeszów to provide access to this document.

267 Ibid., letter to Łoś from 27 July 1926, k. 19.

268 "Listy Józefa Piłsudskiego", ed. K. Świtalski, Niepodległość (Nowy Jork and Londyn), vol. 7 (1962), p. 126. Switalski promised the Professor that he would not repeat it to Piłsudski.

269 “Z rękopisu Prezydenta RP Augusta Zaleskiego z lutego 1957”, PISM, Col. 424/3 (Zaleski's files), p. 3 (unpublished text, in response to Kajetan Morawski's article "Przewrót majowy" in London Wiadomości, no. 566, 3 February 1957).

270 A monographic discussion of the short but rich in events and decisions ministerial term of this politician would be useful.

271 Andrzej Zahorski incorrectly states that it was until October 1923.

272 These were as follows: Konstanty Skirmunt (11 July 1923 - 6 May 1924), Aleksander Skrzyński, Kajetan Morawski, Franciszek Sokal (1926-1932), Tadeusz Gwiazdoski (as a chargé d'affaires), 
duality of Polish politics that prevailed in 1918-1922. Due to these conditions, the position of Askenazy was rather complicated - the degree of distrust around him was considerable. National Democrats considered him Piłsudski's man, the latter probably did not have full confidence in him. Paderewski's circle saw Askenazy as one of the spokesmen of the activism camp, discredited by history. He had most in common with people of the Polish Socialist Party (such as Daszyński), although he was not a socialist - but socialists never had much influence on foreign policy, except for the short period of the National Defence Government in the second half of 1920. The foreign policy of the first years of the new Poland was led in the shadow of an acute internal power struggle in the reborn state.

(3) Askenazy was the spokesman for the concept of double consciousness of Jews: Jewish, naturally, but also Polish. Jews should preserve their religion and culture, but at the same time "let them combine it with a sense of Polishness and Polish patriotism", as he "retained and worshipped his Jewishness, but at the same time grew deeply into Polish culture and was this culture's co-creator". ${ }^{273}$

(4) "Askenazy is one of a relatively small group of historians who have, successfully or not, actively participated in politics, they were politicians", said Pajewski. ${ }^{274}$ We should therefore remember about the historian of the European format who at a turning point for our nation's fate was also a diplomat, placed in the centre of events of great importance. He represented the interests of the reborn Poland, his homeland of choice. He achieved a lot - but his actions did not meet with universal approval of the main camps of Polish politics. The memory of the contributions of the outstanding historian has obscured his participation in active public service and complete identification with the Polish state interests, understood as a fight for a territorially significant and independent state, in a remarkably unfavourable geopolitical constellation.

\section{Bibliography}

\section{Archival materials}

Archives of New Records (Archiwum Akt Nowych), Akta Erazma Piltza, sign. 32.

Archives de la Société des Nations (Geneva): Fonds du Sécretariat Général. Section Politique; Fonds Prives, Drummond Papers 1919-1930.

Archives du Ministère des Affaires Étrangères (Paryż), Europe 1918-1940, Pologne.

State Archives in Lublin (Archiwum Państwowe w Lublinie), zespół Archiwum Łosiów z Niemiec.

Edward Raczyński (1932-1934) and Tytus Komarnicki (1934-1939). A monograph of the Polish delegation at the League of Nations would be useful (Rocznik służby zagranicznej wedlug stanu na 1 kwietnia 1938 r. Warszawa, 1938, p. 161).

273 J. Pajewski, Budowa Drugiej Rzeczypospolitej 1918-1926, 2nd ed. Poznań, 2007, p. 163.

274 J. Pajewski, Poza wczoraj. Wspomnienia, Poznań, 1992, p. 76. 
Jozef Pilsudski Institute of America (New York), archival collection "General Adjutancy of the Commander-in-Chief", box 32.

The Polish Institute and Sikorski Museum in London, Polish Ambassy in London, no. A12.52/2, no. A.12.53/45, no. A.12.49/3.

Politisches Archiv des Auswärtigen Amtes (Berlin), Botschaft Warschau, box 20, Bd. 2: 1921-1922

TNA, Foreign Office 371.

\section{Published sources}

Archiwum Polityczne Ignacego Paderewskiego, vol. 6, 1915-1941, Warszawa, 2007.

Dąbrowski W., Górny Śląsk w walce o zjednoczenie z Polską (Źródła i dokumenty z lat 19181922), Katowice, 1923.

DBFP, First Series, vol. XI, London, 1961.

Documents diplomatiques concernant les relations polono-lithuaniennes, vol. 1, Varsovie, 1921. Documents on British Foreign Policy 1919-1939, First Series, vol. XI, London, 1961.

Kumaniecki K.W., Odbudowa państwowości polskiej. Najważniejsze dokumenty 1912 - styczeń 1924, Warszawa and Kraków, 1924.

Protokoły Komitetu Politycznego Rady Ministrów 1921-1926, ed. M. Jabłonowski, W. Janowski, Warszawa and Pułtusk, 2004.

Sierpowski S. (ed.), Źródła do historii powszechnej okresu międzywojennego, vol. 2, 1927-1934, Poznań, 1992.

\section{Secondary literature}

Askenazy S., Gdańsk a Polska, Poznań, Wilno and Zakopane, 1919.

Askenazy S., Wczasy historyczne, II, Warszawa - Kraków, 1904.

Baranowski W., Rozmowy z Piłsudskim 1916-1931, Warszawa, 1938.

Bardach J., Projekty organizacji kantonalnej Litwy oraz konfederacji polsko-litewskiej w 1921 roku, in: id., O dawnej i niedawnej Litwie, Poznań, 1988.

Barycz H., Na przełomie dwóch stuleci. Z dziejów polskiej humanistyki w dobie Młodej Polski, Wrocław, 1977.

Batowski H., Między dwiema wojnami 1919-1939. Zarys historii dyplomatycznej, Kraków, 1988. Batowski H., Zachód wobec granic Polski 1920-1940. Niektóre fakty mniej znane, Łódź, 1995. Bobrzyński M., Wskrzeszenie państwa polskiego, vol. 2: 1918-1923, Kraków, 1925.

Borzęcki J., The Soviet-Polish Peace of 1921 and the Creation of Interwar Europe, New Haven, 2008.

Cienciała A.M., Komarnicki T., From Versailles to Locarno. Keys to Polish Foreign Policy 19191925, Kansas University Press, 1984.

Davies N., Lloyd George i Polska 1919-1920, Gdańsk, 2000.

Dyplomaci II RP w świetle raportów Quai d’Orsay, ed. J. Łaptos, Warszawa, 1993.

Dyplomacja bez listów uwierzytelniających. Polityka zagraniczna Adama Jerzego Czartoryskiego 1830-1840, transl. M. Borkowicz, Warszawa, 1987.

Grabski W., Wspomnienia ze Spa, ed. Stanisław Kirkor, London, 1973.

Hauser P., Powrót na mapę. Walka o granice państwa polskiego po I wojnie światowej, Poznań, 2010.

Hymans P., Mémoires, vol. 1, Bruxelles, 1958.

Iwaszkiewicz J., “Szymon Askenazy 1867-1935”, Ateneum Wileńskie 11 (1936).

Journal du général Edmond Buat 1914-1923, ed. F. Guelton, Paris, 2015. 
Kamiński M.K., Zacharias M.J., W cieniu zagrożenia. Polityka zagraniczna RP 1918-1939, 2nd ed., Warszawa, 1993.

Kornat M., "Józef Beck - zarys biografii politycznej (1894-1932)”, Niepodległość (Warszawa), vol. 55 (35 after resumption), 2005.

Kornat M., "W przededniu wojny. Żądania niemieckie wobec Polski 1938-1939”, Przegląd Polityczny 95 (2009).

Kukiel M., "Szymon Askenazy”, Przeglad Współczesny 54 (1935), p. 332.

Kukiel M., Generat Sikorski. Żołnierz i mąż stanu Polski Walczącej, London, 1970.

Kukułka J., Francja a Polska po traktacie wersalskim 1919-1922, Warszawa, 1970.

Kułakowski M. (J. Zieliński), Roman Dmowski w świetle listów i wspomnień, London, 1968.

Laroche J., "La Question de Teschen devant la Conference de la Paix", Revue d'Histoire Diplomatique 62 (1948).

Lechoń J., Dziennik, Warszawa, 1993

Leinwand A., "Walka dyplomatyczna Polski o Galicję Wschodnią (1918-1923)", Studia z Dziejów Rosji i Europy Wschodniej 46 (2011).

“Listy Józefa Piłsudskiego", ed. K. Świtalski, Niepodległość (Nowy Jork i Londyn), vol. 7 (1962).

Łossowski P., Kłajpeda kontra Memel. Problem Kłajpedy w latach 1918-1939-1945, Warszawa, 2007.

Łossowski P., Konflikt polsko-litewski 1918-1920, Warszawa, 1996.

Łossowski P., Po tej i tamtej stronie Niemna. Stosunki polsko-litewskie 1883-1939, Warszawa, 1985.

Łossowski P., Stosunki polsko-litewskie 1921-1939, Warszawa, 1997.

Lubicz-Zaleski Z., Dziennik nieciagły (1904-1925), ed. M. Willaume, Paris and Łódź, 1998.

Makowski J., Zagadnienie państwowości W. M. Gdańska, Warszawa, 1934.

Meysztowicz J., Czas przeszły dokonany. Wspomnienia ze służby w Ministerstwie Spraw Zagranicznych latach 1932-1939, Kraków, 1984.

Micewski A., Roman Dmowski, Warszawa, 1971.

Micewski A., Z geografii politycznej II Rzeczypospolitej. Szkice, Warszawa, 1984.

Milhaud E., La France avait raison. Sécurité collective, Neuchâtel, 1945.

Milosz O. V. de L., Deux messianismes politiques, précédé de Vilna et la civilisation Européenne, l'alliance des états baltiques, emprise allemande sur la Russie, Paris, 1990.

Nowak A., Pierwsza zdrada Zachodu. 1920 - zapomniany appeasement, Kraków, 2015.

Nowak J., Wspomnienia z ławy rządowej, Kraków, 1938.

Nowak-Kiełbikowa M., Polska - Wielka Brytania w latach 1918-1923, Warszawa, 1975.

Ochota J. [Tadeusz Perkowski], Spór Litwy z Polską, Warszawa, 1935.

Pajewski J., Budowa Drugiej Rzeczypospolitej 1918-1926, ed. 2, Poznań, 2007.

Pisuliński J., Nie tylko Petlura. Kwestia ukraińska w polskiej polityce zagranicznej $w$ latach 1918-1923, Wrocław, 2004.

Piszczkowski T., Anglia a Polska 1914-1939. W świetle dokumentów brytyjskich, London, 1975.

Piszczkowski T., Plebiscyt i Powstania na Górnym Śląku, London, 1972.

Pobóg-Malinowski W., Najnowsza historia polityczna Polski, vol. 2: 1914-1939, Gdańsk, 1990.

Polska polityka zagraniczna w latach 1926-1932. Na podstawie szkiców mim. Józefa Becka, ed. A. M.Cienciała, Paris, 1990.

"Protokoły Rady Obrony Państwa", eds. A. Leinwand, J. Molenda, Z Dziejów Stosunków Polsko-Radzieckich, vol. 1 (1965), p. 305.

Rataj M., Pamiętniki, ed. J. Dębski, Warszawa, 1965.

Różański P., Stany Zjednoczone wobec kwestii żydowskiej w Polsce 1918-1921, Gdańsk, 2007.

Schimitzek S., Drogi i bezdroża minionej epoki. Wspomnienia z lat pracy w MSZ 1920-1939, Warszawa, 1976. 
Serejski M.H., "Jak ważyły się losy Gdańska przed ostatnią decyzją zwycięskich mocarstw", Dzieje Najnowsze 2 (1970), no. 1.

Seyda M., Polska na przełomie dziejów. Fakty i dokumenty. Od zbrojnego wystąpienia Stanów Zjednoczonych do końca wojny, Poznań i Warszawa, 1931.

Sharp A., David Lloyd George. Great Britain, London, 2008.

Sierpowski S., Liga Narodów w latach 1919-1926, Wrocław i Warszawa, 2005.

Skubiszewski K., "Kompetencje państwa polskiego w Wolnym Mieście Gdańsku”, Czasopismo Prawno-Historyczne 11 (1959), no. 2.

Stauffer P., Polacy, Żydzi, Szwajcarzy, Warszawa, 2008.

Stępniak H., Polska i Wolne Miasto Gdańsk (1920-1939), Gdańsk, 2004.

Suleja W., "Geneza odezwy Naczelnika Państwa do mieszkańców byłego Wielkiego Księstwa Litewskiego z kwietnia 1919”, Niepodległość 25 (1992).

Świtalski K., Diariusz 1919-1935, eds. A. Garlicki, R. Świętek, Warszawa, 1992.

Szczepański A., Górny Śląsk w świetle Konwencji Genewskiej, Warszawa, 1929.

Tyrowicz M., "Aszkenaze Stefan Tobiasz (1863-1920)", Polski Słownik Biograficzny, vol. 1 (1935).

Wandycz P.S., France and her Eastern Allies 1918-1925. French-Czechoslovak-Polish Relations from Paris Peace Conference to Locarno, Minneapolis, 1962.

Wandycz P., "Konferencja w Spa", Kultura 6 (1959).

Wielhorski W., Polska a Litwa. Stosunki wzajemne w biegu dziejów, London, 1947.

Wisner H., Litwa. Dzieje państwa i narodu, Warszawa, 1999.

Wisner H., Wojna nie wojna. Szkice z przeszłości polsko-litewskiej, Warszawa, 1978.

Wołos M., O Piłsudskim, Dmowskim i zamachu majowym. Dyplomacja sowiecka wobec Polski w okresie kryzysu politycznego 1925-1926, Kraków, 2013.

Zaks Z., "Sprawa Galicji Wschodniej w Lidze Narodów (1920-1922)", Najnowsze Dzieje Polski. Materiaty i Studia z Okresu 1914-1939 12 (1967).

Zaks Z., "Walka dyplomatyczna o naftę wschodniogalicyjską (1918-1923)", Z Dziejów Stosunków Polsko-Radzieckich. Studia i Materiały 4 (1969).

Žepkaitè R., Lietuviu tautos kova dèl Vilniaus 1919-1939 m., Vilnius, 1964.

Zięba A., Lobbing dla Ukrainy w Europie międzywojennej. Ukraińskie Biuro Prasowe w Londynie oraz jego konkurenci polityczni (do roku 1932), Kraków, 2010.

Marek Kornat, professor, Institute of History of the Polish Academy of Sciences and Cardinal Wyszynski University; historian and publicist, head of the Centre for the Study of Totalitarian Regimes and the Second World War in the Institute of History of the Polish Academy of Sciences in Warsaw. Research interests: history of diplomacy and international relations in the 19th and 20th centuries, Polish foreign policy in the years 1918-1945, the history of Polish and western Sovietological studies. His publications include: Polityka zagraniczna Polski 19381939. Cztery decyzje Józefa Becka (Gdańsk, 2012); Polskie Dokumenty Dyplomatyczne. 1938 (Warszawa, 2007) (m_kornat@o2.pl). 